\title{
Risk indicators affecting honeybee colony survival in Europe: one year of surveillance
}

\author{
Marie-Pierre ChAUZAT ${ }^{1,2}$, Antoine $\mathrm{JACQUES}^{1}{ }^{1}$, EPILOBEE consortium ${ }^{4}$, \\ Marion Laurent ${ }^{2}$, Stéphanie Bougeard ${ }^{3}$, Pascal HENDrikx ${ }^{1}$, Magali Ribière-ChaberT ${ }^{2}$ \\ ${ }^{1}$ Unit of Coordination and Support to Surveillance, Scientific Affairs Department for Laboratories, ANSES, Maisons- \\ Alfort, France \\ ${ }^{2}$ Unit of Honeybee Pathology, European Union and National Reference Laboratory for Honeybee Health, ANSES, \\ Sophia Antipolis, France \\ ${ }^{3}$ Unit of Epidemiology and Welfare of Pork, ANSES, Ploufragan, France
}

Received 7 July 2015 - Revised 27 January 2016 - Accepted 4 March 2016

\begin{abstract}
The first pan-European harmonized active epidemiological surveillance program on honeybee colony mortality (EPILOBEE) was set up across 17 European Member States to estimate honeybee colony mortality over winter and during the beekeeping season. In nine Member States, overwinter losses were higher and statistically different from the empirical level of $10 \%$ under which the level of overwinter mortality was considered as acceptable with usual beekeeping conditions. In four other countries, these losses were lower. Using multivariable Poisson regression models, it was showed that the size of the operation and apiary and the clinically detected varroosis, American foulbrood (AFB), and nosemosis before winter significantly affected 2012-2013 overwinter losses. Clinically detected diseases, the size of the operation and apiary, and the non-participation to a common veterinary treatment significantly affected 2013 summer losses. EPILOBEE was a prerequisite to implement future projects studying risk factors affecting colony health such as multiple and co-exposure to pesticides.
\end{abstract}

\section{honeybee health / EPILOBEE / epidemiological survey / winter mortality / seasonal mortality}

\section{INTRODUCTION}

Numerous hazards threaten honeybee populations (Apis mellifera) worldwide. Many publications that looked into colony losses from any part of the world reported that several biological and environmental factors acting alone or in combination have the potential to cause premature colony mortality (Genersch et al. 2010; Potts et al. 2010;

Electronic supplementary material The online version of this article (doi:10.1007/s13592-016-0440-z) contains supplementary material, which is available to authorized users.

Corresponding author: M. Chauzat, mariepierre.chauzat@anses.fr Manuscript editor: Yves Le Conte EPILOBEE Consortium The full author list and affiliations are given in the Annex.
Spleen et al. 2013). In the USA and Canada, alarming losses of honeybee colonies were recently reported (Steinhauer et al. 2014). In Europe, the decrease in honeybee colonies was estimated at $16 \%$ between 1985 and 2005 and the reduction of beekeepers at $31 \%$ (Potts et al. 2010). However, these figures on the decline in the number of managed honeybee colonies in Europe are mainly influenced by socioeconomic factors (Vanengelsdorp and Meixner 2010; Aizen and Harder 2009) and must not be confused with colony losses (meaning the death of honeybee colonies) over winter or during the season (McMenamin and Genersch 2015). At the European level, the COLOSS initiative (= Prevention of honeybee COlony LOSSes) had already allowed to document colony losses in Europe on a broad population (19 countries returning data from 15,850 beekeepers with 279,523 colonies in 
2012). COLOSS has collated data throughout the distribution of a standardized questionnaire filled and sent back by the beekeepers (van der Zee et al. 2014). Following a study on honeybee health surveillance systems financed by EFSA, the need to implement standardized representative systems on bee health has been highlighted (Hendrikx et al. 2010). Hence, to complete the approach, an extended epidemiological project has been set up at the European level to assess honeybee colony mortality on a representative sample of beekeepers and colonies.

In 2011, the European Commission has requested the technical assistance of the European Reference Laboratory for honeybee health (EU $\mathrm{RL}$ ) to set up and run for 2 years a field study on honeybee colony mortality. Seventeen Member States (MSs) of the European Union (EU), Belgium, Denmark, England and Wales (treated here as one member state), Estonia, Finland, Germany, France, Greece, Hungary, Italy, Latvia, Lithuania, Poland, Portugal, Slovakia, Spain, and Sweden, were gathered in a consortium to set up the first pan-European active epidemiological surveillance program on honeybee colony mortality (EPILOBEE) based on randomly selected apiaries and colonies (Commission 2011; Commission 2012). Member States participating to EPILOBEE covered $80 \%$ of the colonies declared in the EU according to a survey run by the EU RL (Chauzat et al. 2013). The objective of EPILOBEE was to quantify the mortality of honeybee colonies in each MS on a harmonized basis and to estimate the health of the bee population through the assessment of clinical disease prevalence and other information related to beekeeping practices (the honeybee subspecies, the training of the beekeeper or the size of the operation corresponding to the total number of the colonies owned by one beekeeper, and the size of the apiary, for instance).

The honeybee diseases regulated at the European level (i.e., notifiable in the EU, considered in trade and import rules or for national eradication programs) were clinically investigated within the framework of this program together with others (see below) irrespective of the national regulation in force (Chauzat et al. 2014a, b). Varroosis, the main parasitic disease of honeybees, was recorded based on clinical signs directly observed on colonies in the field. This parasitic infestation induces tremendous losses all over the world with some rare exceptions (Locke and Fries 2011). The two main diseases affecting brood, American foulbrood (AFB) and European foulbrood (EFB), caused by the bacteria Paenibacillus larvae and Melissococcus plutonius, respectively, were also assessed. AFB is a highly contagious disease regulated worldwide by OIE and EU-wide by the European Union regulation. EFB induces clinical signs on brood with the death of larvae shortly before being sealed in the cells resulting in a mosaic or spotty brood pattern. A viral disease caused by the chronic bee paralysis virus (CBPV) was also surveyed. The disease nosemosis, caused by the fungus Nosema spp., which has been described as of importance and covered by the OIE manual (OIE 2013) was investigated. Between autumn 2012 and summer 2013, 31,664 colonies located in 3053 apiaries were fully checked three times by 1354 bee inspectors (data extracted from the database in March 2015). The name "bee inspector" is used hereafter to indicate the person in charge of the visits irrespective of his/her qualification/affiliation in the different MS. Overall, 9159 visits of apiaries were implemented in EPILOBEE (data extracted in March 2015). Winter colony mortality rates of EPILOBEE program for the first year (from September 2012 to September 2013) described in earlier reports ranged from 3.2 to $32.4 \%$ with a south-north geographical pattern. In Greece, Hungary, Italy, Lithuania, and Slovakia, winter mortality rates were lower than $10 \%$. In Denmark, Germany, France, Latvia, Poland, Portugal, and Spain, winter mortality rates were between 10 and $20 \%$. In Belgium, England and Wales, Estonia, Finland, and Sweden winter mortality rates were greater than $20 \%$. Overall seasonal mortality rates (during beekeeping season) were lower than winter mortality rates and ranged from 0.02 to $10.5 \%$ (Chauzat et al. 2014a, b).

In the present study, we investigated the statistical links between the colony mortality and some risk indicators including clinical disease prevalence (varroosis, AFB, EFB, chronic bee paralysis, nosemosis), beekeeper age, sanitary measures, and beekeeping characteristics (migratory 
beekeeping, size of the apiary, size of the operation) using the apiary as the epidemiological unit. Two types of mortality were addressed: the winter mortality and the seasonal mortality.

\section{MATERIALS AND METHODS}

The EPILOBEE surveillance was designed to collect data on a representative sample of apiaries and colonies within each MS by the means of onsite investigations. Representativeness has been reached through a random sampling of apiaries in the entire MS. In four MSs (France, Finland, Poland, and Sweden), the protocol was implemented in some regions representative of the MS. In France, Finland, and Poland, six, five, and one administrative units, respectively (NUTS ${ }^{1} 3$ and NUTS 2, respectively), were chosen to be representative of the diversity of the landscape and the beekeeping productions. In Sweden, three regions (NUTS 3) were located in southern part of the countries where the beekeeping activity was well developed, thanks to mild climatic conditions. The sampling was based on a twostage random sampling with apiaries as primary units and bee colonies as the secondary units (Table I). In each MS, beekeepers and apiaries were randomly selected from a national list as complete as possible (refer to guidelines (EURL 2011)). Within each apiary, the appropriate number of colonies was randomly selected in order to be representative of the apiary. This number was calculated using a sample size calculator indicating the number of colonies to be visited in an apiary according to the size of the apiary and to the prevalence targeted (EURL 2011). In 2011, the European Commission (EC) issued a call for all MSs to participate to EPILOBEE (Commission 2011). MSs should send their application to the EC in due time (not all the $27 \mathrm{MSs}$ did send an application). Subsequent to the evaluation, 17 MSs out of 20 that submitted their proposal were selected to take part to the program. The epidemiological proposals were assessed according to a standard methodology based on the evaluation of several criteria to evaluate the compliance with the core protocol and/or the proposed alternatives: the setup of a preliminary census or the assessment of the total honeybee population, the geographical representativeness of the survey, the representativeness of the epidemiological units selected (apiaries selection method and the availability of

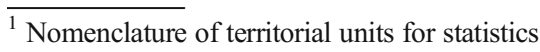

a sampling database), the colony sampling mode within selected apiaries, the precision of the measure at national level (sample size), the inclusion of diseases in the clinical examinations and the systematic biological examination, the compliance with the visit protocol and proposal, the organization of the data management, the availability of sufficient human resources planned to work in the survey, the training planning, and the organization of the animation and the project follow-up and coordination.

To follow the work fulfilled in each MS, the MSs were requested to produce a technical documentin 2013 and 2014 to report the field work implemented during the epidemiological project. The numbers of controlled apiaries declared by the MS in the document were cross-checked with the data stored in the online database. When the agreement between the numbers was above $90 \%$, the figures were accepted as they were meaningful for the statistical analysis. The data were therefore epidemiologically valid. In some cases, minor discrepancies have been noticed between the number of expected apiaries to be visited initially proposed in the MS programs and the actual apiaries visited (Table I). These discrepancies were in all cases justified (e.g., losses of colonies, beekeepers refusing to take part to the surveillance) and did not undermine the final results of the studies. It should be noted that the representativeness of the data depended on the method of selection of the apiaries and colonies (random selection) and not on the number of inspected apiaries and colonies.

There were some minor adjustments on the selection of beekeepers in some MSs. The registration in the list used for the beekeepers random selection was mandatory in most of the MSs (Table I). Professional beekeepers were more frequently registered in national data sets than small beekeepers, as they were subject to official controls related to honey trade (Regulation (EC) 852/2004). This might overrepresent large operations. On the contrary, beekeeper associations may underrepresent such larger operations. In Estonia, Latvia, and Slovakia, the random sampling of beekeepers was risk oriented (colonies were not entirely randomly selected, see Table I). In Germany, the random selection of beekeepers was completed with beekeepers taking part in the German bee monitoring project (Genersch et al. 2010). In Spain, Greece, and Italy, the random apiary selection was performed subsequent to geographical stratification. In Finland, France, and Sweden, 


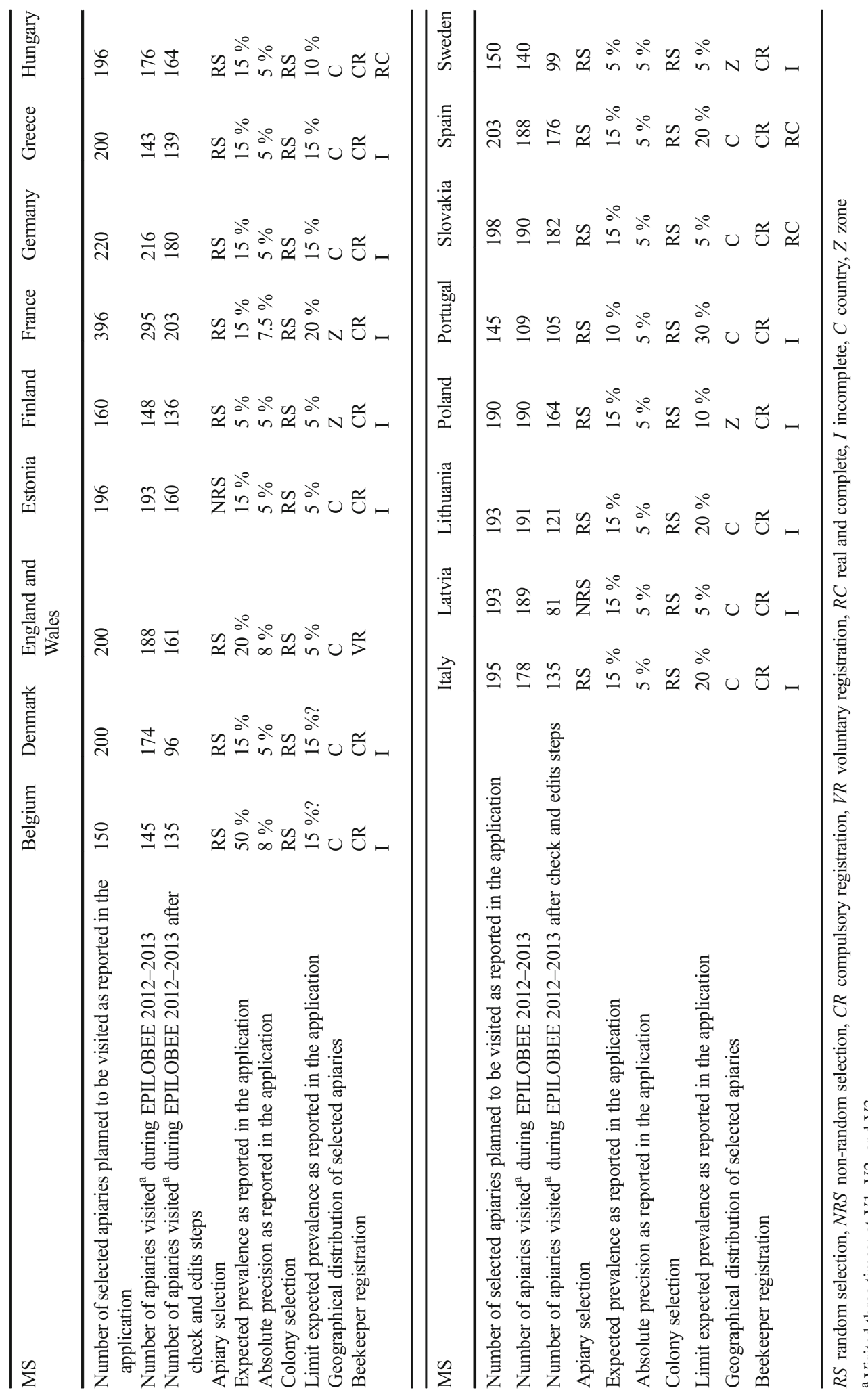


the apiary sampling rate was different according to areas (Table I).

In 2013, the EU RL made a short survey through a questionnaire sent to all MSs taking part in EPILOBEE, to investigate the reasons why some randomly selected beekeepers refused to take part in the program. The following reasons were given starting by the most frequent: the number of honeybees (300) sampled at V1 for the systematic samples could impair colony survival; the person contacted was not a beekeeper anymore; concerns on diagnosis of notifiable disease in the apiary; and lack of time; afraid of the control, of the bad weather, or to weaken the colonies with the visits. In case of refusal, most of the MSs performed a new random selection of beekeepers.

The dataset of the samples used in this study gathered the total number of sampled apiaries from each MS. There was no overall sample frame (all 17 MSs together) used to select the apiaries. Despite the peculiarities of national protocols (sampling frames, list of apiaries, sample size, spatial stratification), the overall data set was harmonized and usable for common calculations (Garin et al. 2014). Data (from the 17 participating MSs) were all collected and stored centrally in a standardized way using an online database via a website developed by the EU RL and the French epidemiological surveillance platform for animal health.

\subsection{Surveillance protocol}

To estimate the mortality of bee colonies over the winter and during the beekeeping season, three visits were performed by bee inspectors: before winter 2012 (autumn 2012, V1), after winter 2012 (spring 2013, V2), and during the beekeeping season (summer 2013, V3). A colony was considered suffering from winter mortality if during V1, the colony was recorded alive by the bee inspector and was previously estimated capable of overwintering by the beekeeper and during V2 the colony hosted some honeybees but was considered nonviable (nearly dead $=$ less than 500 honeybees in the colony) and could not start again for the beekeeping season, according to the bee inspector expertise, or the colony was in one of the following situations: all the honeybees were dead within the hive, all the honeybees were dead and the hive was empty, and the colony hosted laying workers with no queen. A colony was considered suffering from seasonal mortality if during $\mathrm{V} 2$, the colony was recorded alive by the bee inspector and was previously estimated capable of surviving the season by the beekeeper, and during V3, the colony hosted some honeybees but was considered non-viable and could not continue the beekeeping season, according to the bee inspector expertise; or the colony had one of the clinical signs identical to those mentioned for the winter mortality; or the colony was merged with another between V2 and V3. Therefore, when two colonies were merged, one was registered as dead colony.

Management practices and clinical signs observed by the beekeepers during the interval preceding the visit were recorded through a detailed questionnaire. Each selected colony was visited and fully examined by experts for clinical signs of the main honeybee diseases.

If a colony exhibited clinical signs for one of the diseases investigated within the framework of this project at any visit, affected brood and/or adult bees were sampled for subsequent laboratory confirmation. In this study, only the laboratory results obtained on the samples collected from the colonies with clinical signs of the diseases listed above were reported. Because of colony visits and honeybee sampling for Varroa mites, EPILOBEE gave also the opportunity to the MSs for training and improvement of the detection of Aethina tumida (Coleoptera: Nitidulidae) and Tropilaelaps mites, two exotic pests to Europe, at the time of sampling. For that matter, the EU RL provided the MSs with leaflets for the detection of these pests in 2012. ${ }^{2}$ Any specimen collected in the field, and considered as suspect by the NRL, should have been sent to the EU RL for diagnosis confirmation. The search of pesticide residues was not included in this pilot project.

\subsection{Environment}

Beekeeper and bee inspectors reported in the questionnaire the environment surrounding the apiary in four categories: farmlands (FA), wild natural flora (FL), orchards (OR), town (TO), and any of the combinations possible, by two, three, or the four options. It was also possible to select the null option (no environment reported). This classification leads to 16 categories. In the questionnaire, it was also mentioned the possibility to tick forests and woods and industries and motorways. However, these two categories were discarded from the

\footnotetext{
$\overline{{ }^{2} \text { Available at https://sites.anses.fr/en/minisite/abeilles/free- }}$ access-documents- 0
} 
statistical analysis as they were not often selected in the questionnaires.

\subsection{Calculation of the clinical prevalence of the diseases at the apiary level}

The case definitions have been agreed between the MSs and the EU RL during several workshops over the course of the project. Synthetic descriptive forms have been distributed to list and illustrate clinical signs of the diseases. Any colony was considered positive with varroosis if any laboratory analysis diagnosed the disease with or without parasite detection on adult honeybees in the colony and/or if typical clinical signs were recorded in the field-presence of Varroa mites, honeybees with deformed and/or atrophied wings, and honeybees with a small abdomen; on brood — spotty brood pattern, presence of mites (brown mature females, white immature stages), capping with small holes, light brown to brown dead larvae, dried dead larvae, dead honeybees with deformed wings in sealed cells and/or dead pupae and/or dead emerging honeybees (only the head emerge, with the tongue sticking out), and cannibalism on larvae or pupae. Any colony infected with P. larvae and presenting clinical signs as followed was considered suffering from AFB: spotty brood pattern, capping with different color, dark sunken cell capping, holes in capping, ropy larvae, coffee brown color larvae, sticky scales, and specific odor of the sick larvae. Any colony infected with $M$. plutonius and presenting clinical signs as followed was considered suffering from EFB: spotty brood pattern, capping with holes, slumped larvae, larvae with a yellowish to brown color (generally in unsealed brood), and vinegar or putrefaction odor of the larvae. Any colony infected with CBPV viral load superior to $10^{8}$ copies of the viral genome per honeybee and presenting clinical signs as followed was considered suffering from chronic paralysis: trembling honeybees, crawling honeybees, dead honeybees in front of the hive, small black honeybees, shiny and hairless rejected from the hive, honeybees rejected by guards, flying board occupied by bees, and diarrhea.

The clinical prevalence of the diseases was based on the proportion of apiaries clinically affected by a disease out of the number of visited apiaries. An apiary was considered affected by a disease if at least one of the colonies exhibited clinical signs of the disease and the disease was confirmed by a laboratory analysis.

\subsection{Selection of risk indicators}

After a Delphi-like selection based on the choice by four experts from ANSES agency (Powell 2003), a reduced number of risk indicators out of the 138 variables available in the database (Table S1) were retained to be included in the present statistical analysis: the country, the beekeeper age, whether the beekeeper was taking part to a common veterinary treatment (for the control of Varroa mite infestation), if the apiary was migratory, the environmental surroundings, the population size of the apiary selected, the overall size of the beekeeping operation (total number of colonies belonging to the beekeeper), and whether the apiary was affected by the clinical diseases listed above (Table II) at V1 or V2. This paper focuses on winter and seasonal mortality and the links with diseases reported before mortality (V1 or V2). Therefore, diseases observed at $\mathrm{V} 3$ were not reported in the paper.

\subsection{Data management and processing}

Such a large, multi-state program recording 9159 visits and more than 109,598 laboratory analyses induced the evident risk of error in the recorded data (data extracted in March 2015). Several classical cleaning steps of the data allowed the control and the deletion of errors. The 12 variables retained for the analysis were carefully checked using $R$ codes ( $\mathrm{R}$ software, version 3.1.2) to identify duplicates or nonsense data. For example, the numbers of selected colonies should be the same between V1 and V2 or the number of colonies reported alive or dead at any visit should be less than or equal to the number of selected colonies. In total, 12 cleaning steps and four edits were applied to the data set (Table S2). Remaining incorrect and missing data were discarded from calculation. After these cleaning and edit steps, 2437 out of the 3053 apiaries fully visited were retained for the statistical analysis. In 45 apiaries out of the 2437 apiaries, all the colonies died between V1 and V2. These particular cases were not taken into account for the study of the seasonal mortality, due to the impossibility to calculate the seasonal mortality. Finally, 2437 apiaries were taken into account for the study of the winter mortality and 2392 for the study of the seasonal mortality. Portuguese data were only included for the analysis of the variable country. The 
Table II. The 12 variables retained in the statistical analysis to study risk indicators affecting honeybee colony mortality.

\begin{tabular}{ll}
\hline Variable & Categories \\
\hline Country & Belgium, Denmark, England and Wales, Estonia, Finland, France, Germany, Greece, \\
& Hungary, Italy, Latvia, Lithuania, Poland, Portugal, Slovakia, Spain, Sweden \\
Beekeeper age & $<30$ years, 30-45 years, 46-65 years, $>65$ years \\
$\begin{array}{l}\text { Participation to a common } \\
\text { veterinary treatment }\end{array}$ & Yes, no \\
Migration & Yes, no \\
Environment & FA, FL, OR, TO, FA_FL, FA_OR, FA_TO, FL_TO, OR_FL, OR_TO, FA_FL_TO, \\
& FA_OR_FL, FA_OR_TO, OR_FL_TO, FA_OR_FL_TO, none \\
Apiary size & $\leq 5$ colonies, 6-10 colonies, 11-20 colonies, 21-50 colonies, $>50$ colonies \\
Size of the operation & $\leq 50$ colonies, 51-100 colonies, 101-150 colonies, 151-200 colonies, 201-300 \\
& colonies, $>300$ colonies \\
Varroosis at V1 or V2 & Not suffering, suffering \\
AFB at V1 or V2 & Not suffering, suffering \\
EFB at V1 or V2 ${ }^{\text {a }}$ & Not suffering, suffering \\
Nosemosis V1 or V2 & Not suffering, suffering \\
Chronic bee paralysis V1 or V2 & Not suffering, suffering \\
\hline
\end{tabular}

$F A$ farmland, $F L$ floral, $O R$ orchards, $T O$ towns

${ }^{\text {a }}$ See the text for details on statistical methodology

Portuguese data were subsequently removed from the dataset for the rest of the statistical analyses due to radical differences in the implementation of the protocol. The final number of apiaries retained for the analyses (without Portuguese data) was 2332 for the winter mortality and 2290 for the seasonal mortality.

The variable for the environment has been classified in 16 categories as already described. The variable apiary size (number of colonies present in the sampled apiary) was classified in 6 categories according to colony demography in Europe (78 \% of the European operations had less than 50 colonies in 2010, for more information refer to Chauzat et al. (2013)): less than or equal to 5 colonies, from 6 to 10 colonies, from 11 to 20 colonies, from 21 to 50 colonies, and more than 50 colonies. The variable on the size of the operation (total number of colonies owned by the beekeeper) was ordered in 6 categories: less than or equal to 50 colonies, from 51 to 100 colonies, from 101 to 150 colonies, from 151 to 200 colonies, from 201 to 300 colonies, and more than 300 colonies. Both classifications provided balanced categories allowing statistical tests (no over- or underrepresented categories).

\subsection{Statistical analysis}

The aim was to explain the winter mortality on the one hand and the seasonal mortality on the other hand with the explanatory variables selected by the previous Delphi-like analysis. For the winter mortality, the response variable was the number of dead colonies between V1 and V2, while for the seasonal mortality, it was the number of dead colonies between V2 and V3. Rates of mortality were the number of dead colonies between two visits divided by the sum of the colonies alive and the dead colonies between two visits. The epidemiological units being the apiaries, the two response variables (i.e., winter and seasonal mortalities) were considered as count numbers with Poisson distributions. In the following, the models used were the Poisson generalized linear models, also known as loglinear model. In order to take into account the size of the apiary, an offset was added in this log-linear model: for the winter mortality, it equaled to the logarithm of the sum between the number of colonies still alive at V1 and the number of dead colonies between V1 and V2; for the seasonal mortality, 
it equaled to the logarithm of the sum between the number of colonies still alive at $\mathrm{V} 2$ and the number of dead colonies between V2 and V3.

\subsubsection{Univariate analysis}

Each explanatory variable was analyzed to observe its effect on mortalities by means of univariate quasi-Poisson regression models. Variables with a $p$ value associated to the likelihood ratio (LR) less than 0.05 had a statistical significant effect on the winter mortality or on the seasonal mortality (LR statistic followed $\mathrm{chi}^{2}$ distribution). We denoted by « simple effect », the effect of a single explanatory variable on a response variable (without any influence coming from another explanatory variable).

As a complementary analysis, all the explanatory variables (with the exception of the variable country) were analyzed through comparison of mortality rates of each category of the explanatory variable with the mean winter mortality and the mean seasonal mortality of participating countries. To perform these comparisons, for each category of each variable, the response variable (the number of dead colonies between V1 and V2 or between $\mathrm{V} 2$ and $\mathrm{V} 3$ ) was substituted by a ratio in which this number of dead colonies was divided by the mean winter or seasonal mortality. This mean winter-or seasonal-mortality of participating countries was weighted by the number of apiaries composing for each category.

For the variable country, the winter mortality rates of each country were compared to the empirical threshold of $10 \%$. Although no reference values exist for the acceptable level of colony losses during winter, various acceptable rates of winter colony mortality were reported in European countries (Charrière and Neumann 2010; Genersch et al. 2010) and outside Europe (Head et al. 2010; Steinhauer et al. 2014). The seasonal mortality rates of each country were compared to the mean seasonal mortality of participating countries. Only apiaries with correct data for the variable under study were included. Thus, for the univariate models, the studied populations differed from one analysis to another depending on the variable studied in order to maintain as much validated data as possible in the analysis.

\subsubsection{Multivariate analysis}

In order to analyze a complete dataset, missing data were handled by means of an imputation method based on exploratory multivariate analysis (Josse et al. 2012). This imputation method came from an iterative algorithm based on scores and loadings from multivariate analysis, respectively, related to similarities between individuals and relationships between variables. The missing data were not distributed in patches but rather scattered in the different categories. As the explanatory variables to be imputed were all categorical, the multivariate analysis used was the multiple correspondence analysis (MCA). The imputation method was performed using the functions estim_ncpMCA (estimation of the number of dimensions used in the next reconstruction formula) and imputeMCA (imputing data using the number of dimensions previously calculated) from the missMDA R package (http://cran.rproject.org/web/packages/missMDA/index.html). The complete dataset (2332 apiaries for the winter mortality or 2290 for the seasonal mortality) was used in the subsequent steps.

As all the explanatory variables could not be included in a single model, a selection of explanatory variable was performed: only explanatory variables that were related to winter mortality on the one hand or to the seasonal mortality on the other hand with a $p$ value lower than 0.20 were selected. As generalized linear models may be affected by quasi-collinearity between explanatory variables, correlations between these latter variables were controlled. In order to reduce multicollinearity, a twostep method was implemented.

The first one consisted in clustering observations on a set of several correlated and homogeneous explanatory variables (i.e., variables focusing on the same thematic, like all the variables related to diseases, all the variables related to the sizes...). This clustering of observation was performed in order to identify associations between variables: it was achieved by means of a MCA followed by a hierarchical clustering on the main principal components (Greenacre 1984). These methods were performed using the imputeMCA and HCPC functions, respectively, from the missMDA and FactoMineR $\mathrm{R}$ packages (http://cran.r-project.org/web/packages/ missMDA/index.html).

The second step consisted in selecting the best combinations of these explanatory variables by using a forward stepwise-based selection procedure. A bootstrap resampling technique was performed, in 
order to strengthen the best combinations of explanatory variables provided by the forward stepwisebased selection procedure. This was achieved by means of the qselection and test functions from the FWDselect R package (Sestelo et al. 2013). Finally and to explain each mortality, the selected explanatory variables and their second-order interactions were included as fixed effects in mixed multivariable Poisson regression models, the country effect being considered as a random effect in the analysis. A backward selection procedure was used to get the final models. All the models were performed using the glmer function from the lme4 $\mathrm{R}$ package with a log link (http://cran.r-project.org/ web/packages/lme4/index.html).

\section{RESULTS}

\subsection{Univariate analyses}

Among the 12 explanatory variables, nine variables had a statistical significant effect on the winter mortality: the country $\left(p=8.81 \cdot 10^{-29}\right)$, the beekeeper age ( $p=0.03$ ), the migratory apiary $(p=0.01)$, the environmental surrounding $\left(p=1.27 \cdot 10^{-4}\right)$, the size of the apiary $\left(p=5.29 \cdot 10^{-29}\right)$, the size of the operation $\left(p=9.59 \cdot 10^{-3}\right)$, the varroosis at V1 $\left(p=5.74 \cdot 10^{-6}\right)$, the AFB at V1 $\left(p=7.74 \cdot 10^{-10}\right)$, and the nosemosis at V1 $\left(p=1.37 \cdot 10^{-3}\right)$.

For the seasonal mortality, seven variables had a statistical significant effect: the country $\left(p=1.70 \cdot 10^{-17}\right)$, the participation to a common veterinary treatment $\left(p=6.64 \cdot 10^{-4}\right)$, migratory apiary $\left(p=4.09 \cdot 10^{-7}\right)$, the size of the apiary $\left(p=5.55 \cdot 10^{-12}\right)$, the size of the operation $\left(p=6.47 \cdot 10^{-3}\right)$, the AFB at V2 $\left(p=5.38 \cdot 10^{-7}\right)$, and the EFB at V2 $\left(p=1.66 \cdot 10^{-5}\right)$.

In the following paragraphs, the distribution of the apiaries was based on the number of apiaries studied for the winter mortality.

\subsubsection{European member states}

The number of apiaries under study (2437 apiaries for the winter mortality) ranged from 81 in Latvia $(3.32 \%$ of the total number of apiaries assessed) to 203 in France (8.33\%) (Figure 1). The winter mortality rates of each MS were compared to the empirical threshold of $10 \%$. The winter mortality rate was statistically different from $10 \%$ in 13 countries: Belgium, Denmark, England and Wales, Estonia, Finland, France, Greece, Italy, Latvia, Lithuania, Portugal, Slovakia, and Sweden. In Greece, Italy, Lithuania, and Slovakia, the winter mortality rates were below the threshold. In the nine other countries, the winter mortality rates were greater than $10 \%$ (Figure $2 \mathrm{a}$ ). The mean winter mortality of participating countries was $15.02 \%$.

The seasonal mortality rates of each MS were compared to the mean seasonal mortality of participating countries (i.e., $4.01 \%$, Figure $2 b$ ). The seasonal mortality rates from England and Wales, France, Hungary, Latvia, Lithuania, Poland, Slovakia, and Spain were statistically different from the mean seasonal mortality of participating countries. Seasonal mortality rates were greater than the mean seasonal mortality of participating countries (i.e., $4.01 \%$ ) for England and Wales, France, and Spain; while in Hungary, Latvia, Lithuania, Poland, and Slovakia, the seasonal mortality rates were lower than the mean seasonal mortality.

\subsubsection{Beekeeper age}

Most of the beekeepers (2094 apiaries were included for the study of the winter mortality and 2055 for the seasonal mortality) were between 46 and 65 years of age (47.37\%). Beekeepers over 65 years represented $25.17 \%$ of the total population under study, while participants between 30 and 45 years represented for $23.11 \%$. Winter (14.69\%) and seasonal (3.48 \%) mortality rates were the highest in apiaries belonging to beekeepers who were over 65 years of age. Winter mortality rates in all age classes were compared to the mean winter mortality of participating countries (i.e., $12.70 \%$ for these 2094 apiaries). The winter mortality rate in apiaries belonging to beekeepers older than 65 years $\left(14.69 \%, p=4 \cdot 10^{-3}\right)$ and the one in apiaries belonging to beekeepers 45 and 65 years $(10.93 \%, p=0.04)$ were statistically different from the mean winter mortality of participating countries (Table III).

No statistical difference was detected between the seasonal mortality rates for all age classes 


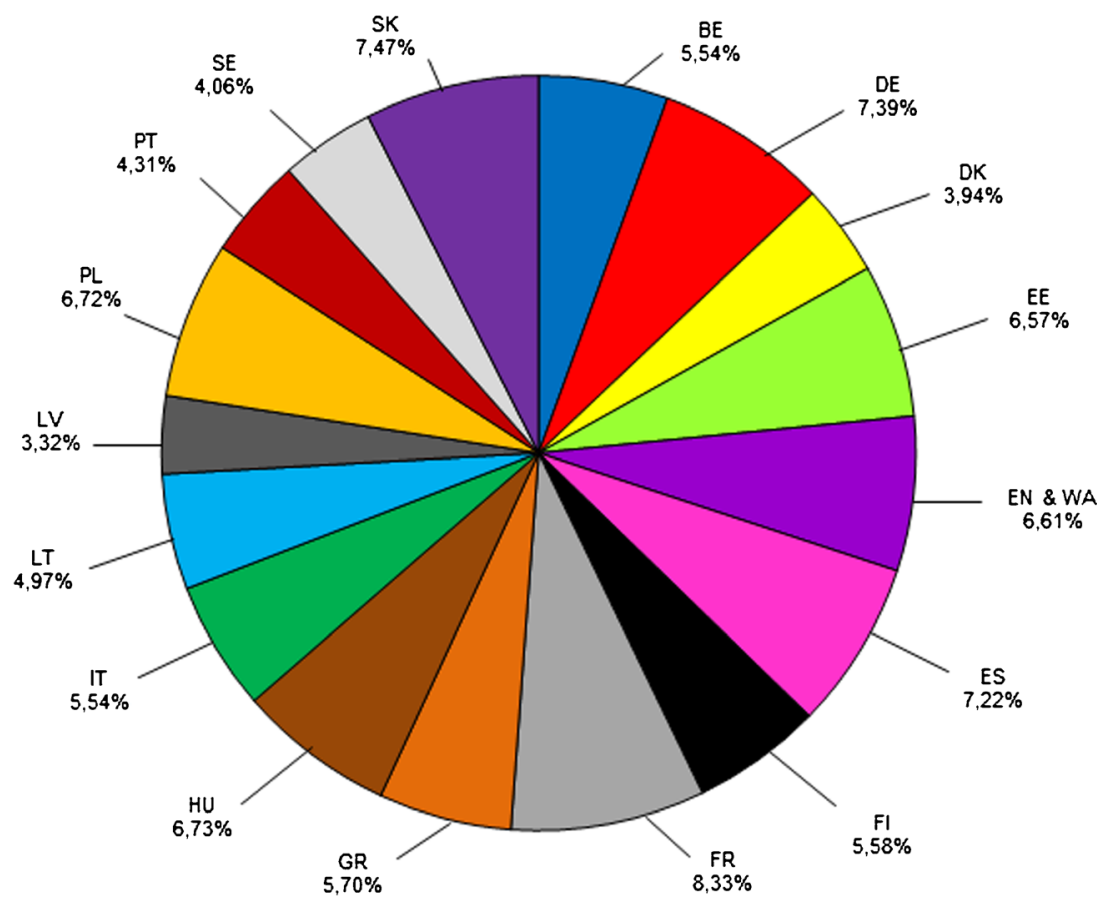

Figure 1. Distribution between MSs of the apiaries surveyed in EPILOBEE 2012-2013. The proportion (\%) for each MS was given under each MS initials and was based on the 2437 apiaries studied for the winter mortality. $B E$ Belgium, $D E$ Germany, DK Denmark, EE Estonia, EN and WA England and Wales, ES Spain, FI Finland, FR France, GR Greece, $H U$ Hungary, IT Italy, $L T$ Lithuania, $L V$ Latvia, $P L$ Poland, $P T$ Portugal, $S E$ Sweden, $S K$ Slovakia.

when compared to the mean seasonal mortality of participating countries (i.e., $3.06 \%$ ).

\subsubsection{Size of the apiaries}

The small apiaries (less than or equal to five colonies) were the most frequent $(28.47 \%$ ) out of the total number of apiaries under study (2332 for the study of the winter mortality and 2290 for the seasonal mortality). Apiaries within the class of 6 to 10 colonies, 11 to 20 colonies, 21 to 50 colonies, and more than 50 colonies represented, respectively, 19.73, $16.94,16.98$, and $17.88 \%$ of the population under study. The highest winter mortality rates and seasonal mortality rates were observed in the smallest apiaries (19.69 and $4.49 \%$, respectively, Figure 3). Winter mortality rates in small size apiaries (less than or equal to 5 colonies, $19.69 \%, p=2 \cdot 10^{-3}$ and $6-10$ colonies, $18.10 \%, p=9 \cdot 10^{-3}$ ) were higher and statistically different from the mean winter mortality (i.e., $15.14 \%$ ). In larger apiaries (21-50 colonies, $12.69 \%, p=3 \cdot 10^{-3}$; more than 50 colonies, $\left.7.71 \%, p<1 \cdot 10^{-16}\right)$, the winter mortality rates were lower and statistically different from the mean winter mortality (Figure 3 and Table III).

The seasonal mortality rates of these apiaries (21-50 colonies, more than 50 colonies) were also statistically different $(2.67 \%, p=0.04 ; 2.50 \%$, $p=5 \cdot 10^{-3}$, respectively) from the mean seasonal mortality (i.e., $3.51 \%$-Figure 3 and Table III).

\subsubsection{Size of the operation}

Most of the beekeepers (2332 apiaries for the study of the winter mortality and 2290 for the seasonal mortality) managed small operations (less than or equal to 50 colonies, $70.50 \%$ ). Operations between 51 and 100 colonies, 101-150 colonies, 151-200, 201-300, and more than 300 colonies represented, respectively, 10.72, 4.55, $3.09,3.39$, and $7.76 \%$ of the population under 

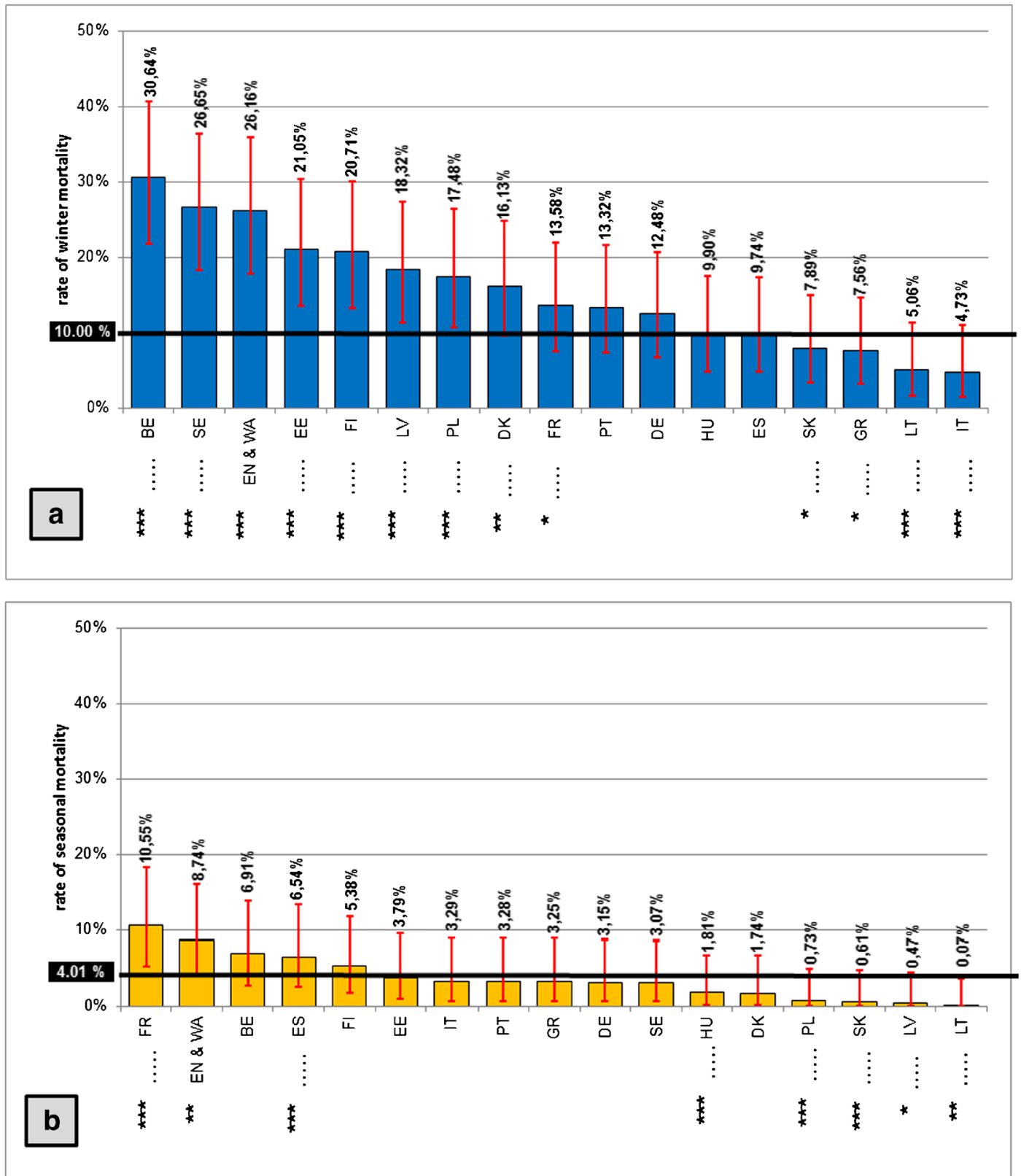

Figure 2. Mortality observed in the 17 MSs taking part in EPILOBEE 2012-2013. Each mean winter mortality rate was compared to the threshold of $10 \%$. Each mean seasonal mortality rate was compared to the mean seasonal mortality of participating countries. The statistical differences are indicated with asterisks $(*=p<0.05$, $* *=p<0.01 ; * * *=p<0.001)$. The red line segments represented the $95 \%$ confidence intervals. a Winter mortality. b Seasonal mortality.

study. The highest winter mortality rates were observed in the small operations $(15.84 \%)$, and the highest seasonal mortality rates were observed in the largest operations $(5.69 \%)$. All the winter mortality rates were statistically different from the mean winter mortality of participating countries (i.e., $13.80 \%$, Figure 4 ) with the exception of operations between 151 and 200 colonies. 

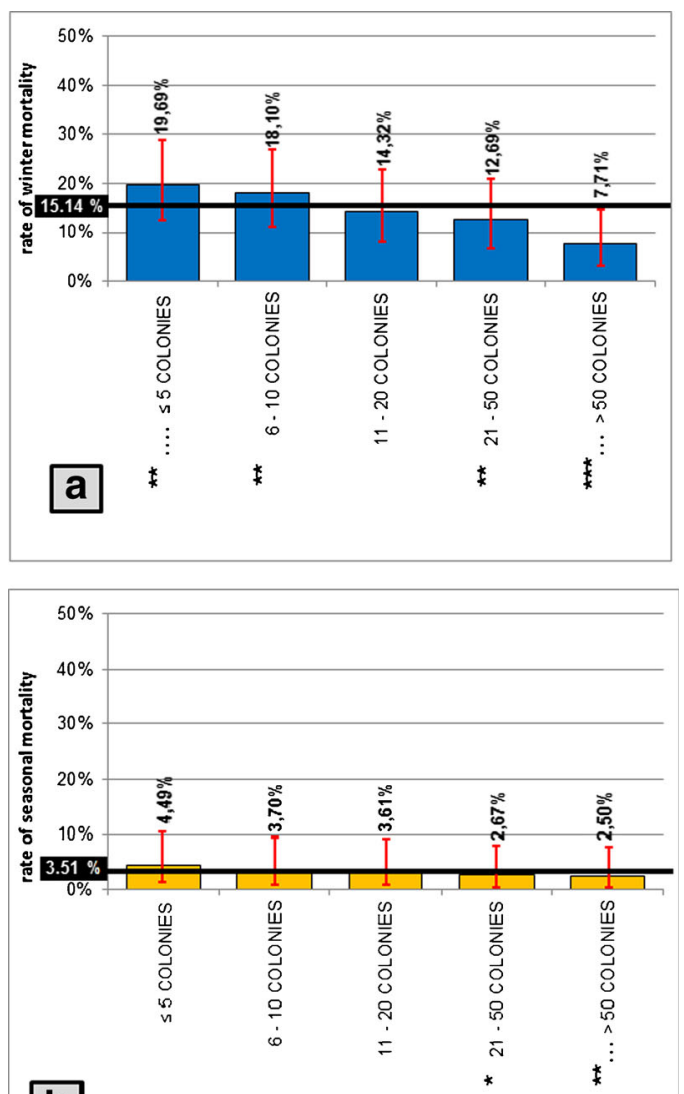

\section{b}

Figure 3. Mortality observed in the MSs taking part in EPILOBEE 2012-2013 depending on the size of the apiary. Each mean mortality rate was compared to the mean mortality of participating countries. The statistical differences are indicated with asterisks $(*=p<0.05$, $* *=p<0.01 ; * * *=p<0.001)$. The red line segments represented the $95 \%$ confidence intervals. a Winter mortality. b Seasonal mortality.

Amongst them, only the winter mortality rate of small operations was higher than the mean winter mortality of participating countries, the others were lower (Figure 4 and Table III).

The seasonal mortality rate in the largest and the small operations (more than 300 colonies and 51-100 colonies) were statistically different $\left(5.69 \%, p=8 \cdot 10^{-5} ; 1.78 \%, p=510^{-3}\right.$, respectively) from the mean seasonal mortality of participating countries (i.e., $3.15 \%$-Figure 4 and Table III).

\subsubsection{Migratory apiaries and participation to a common veterinary treatment program}

An apiary was considered as migratory when most of the colonies (not only the ones under study) were moved to a different location. If only some colonies under study were moved, it was reported in the section related to the colonies inspected; the apiary was not considered migratory in this case. The information on migratory apiaries was reported in 2254 apiaries for the winter mortality and 2213 for the seasonal mortality. Most of the beekeepers had non-migratory apiaries $(74.05 \%)$. The highest winter mortality was observed in those apiaries $(14.47 \% ; 10.41 \%$ for the migratory apiaries) while a slightly higher seasonal mortality rate was observed in migratory apiaries $(3.34 \% ; 3.00 \%$ for the non-migratory apiaries - Table III). The winter mortality rate in non-migratory apiaries was higher and statistically different from the mean winter mortality of participating countries (i.e., $13.42 \%$ ). There was no statistical difference between the seasonal mortality rates of non-migratory and migratory apiaries compared to the mean seasonal mortality of participating countries (i.e., $3.09 \%$ ).

The information on participation to a common veterinary treatment was reported for 2017 apiaries for the winter mortality and 1980 for the seasonal mortality. Most of the apiaries took part to a common veterinary treatment $(55.73 \%)$. Winter $(12.87 \%)$ and seasonal $(3.94 \%)$ mortality rates were slightly higher in apiaries which did not take part to any common veterinary treatment compared to the apiaries which took part to a common veterinary treatment (12.78 and $2.44 \%$ for winter and seasonal mortality, respectively-Table III). There was no statistical difference between the winter mortality rates of apiaries taking part or not to a common veterinary treatment compared to the mean winter mortality of participating countries (i.e., $12.82 \%$ ). Conversely, the seasonal mortality rate of apiaries was statistically different from the mean seasonal mortality of participating countries (i.e., $3.11 \%$ ), whether it was lower $(2.44 \%, p=0.02)$ for the ones participating or higher for the ones not participating in a common veterinary treatment $(3.94 \%, p=0.01)$. 

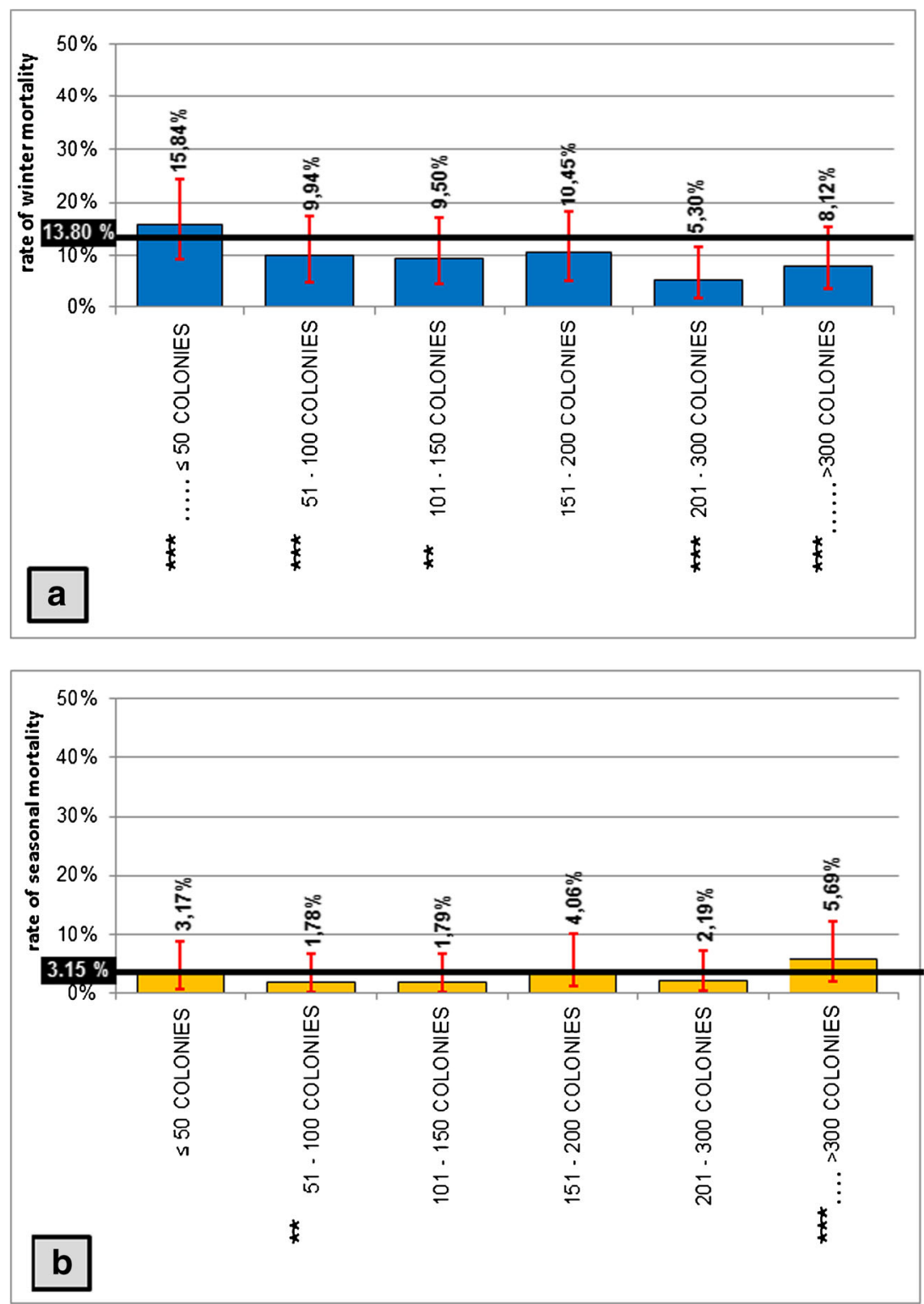

Figure 4. Mortality observed in the MSs taking part in EPILOBEE 2012-2013 depending on the overall size of the operation. Each mean mortality rate was compared to the mean mortality of participating countries. The statistical differences are indicated with asterisks $(*=p<0.05, * *=p<0.01 ; * * *=p<0.001)$. The red line segments represented the $95 \%$ confidence intervals. a Winter mortality. b Seasonal mortality.

\subsubsection{Environment}

The information on the environment was reported in 1808 apiaries for the winter mortality and 1772 for the seasonal mortality. Most of the answers reported the combination of farmland- floral or farmland-floral-orchards $(21.90$ and $21.24 \%$, respectively). Within the 16 categories of this variable, winter mortality rates ranged from $5.11 \%$ (farmland-orchards-town in combination) to $22.47 \%$ (town alone) and seasonal mortality rates ranged from $0.00 \%$ (orchard-town in 
combination) to $4.54 \%$ (flower-town in combination) (Figure 5 and Table III). For the winter mortality, only the rates from the apiaries with an environment with town alone $(22.47 \%$, $p=0.01)$ and farmland-orchards-floral in combination $(14.93 \%, p=0.03)$ were higher and statistically different from the mean winter mortality of participating countries (i.e., $12.93 \%$ ). None of the seasonal mortality rates were statistically different from the mean seasonal mortality of participating countries (i.e., $2.86 \%$ ).

\subsubsection{Diseases}

The five diseases considered in this paper have been clinically observed and laboratory confirmed. The diseases at V1 were studied on 2332 apiaries, while the diseases at V2 on 2290 apiaries. For nosemosis, it should be noted that clinical symptoms included symptoms of dysentery that were typical for Nosema apis infections. Nosema ceranae infections allegedly did not cause dysentery (Higes et al. 2010) and were, therefore, more difficult to diagnose clinically. A few apiaries were clinically affected by nosemosis and chronic bee paralysis at V1 and V2 (0.60 and $7.99 \%$, respectively, for nosemosis and 0.69 and $0.92 \%$, respectively, for chronic bee paralysis). The rates of winter mortality $(21.77 \%$ for nosemosis and $18.92 \%$ for chronic bee paralysis) and seasonal mortality (4.00\% for chronic bee paralysis) were higher in the apiaries affected by the disease (Table III). The winter mortality rate in apiaries affected by nosemosis was higher and statistically different $(p=0.03)$ from mean winter mortality of participating countries (i.e., $12.85 \%$ ). For nosemosis and chronic bee paralysis, the seasonal mortality rates were not statistically different from the mean seasonal mortality of participating countries (3.08 and $3.06 \%$, respectively).

Clinical varroosis was observed in $14.88 \%$ of apiaries at V1 and in $12.79 \%$ of apiaries at V2. The winter mortality rates from the apiaries with clinical sign of varroosis at V1 $(19.15 \%, p=9$ $10^{-9}$ ) and from the apiaries without any clinical signs of varroosis at V1 (11.67\%, $p=0.01$ - Table III) were statistically different from the mean winter mortality of the participating countries (i.e., $12.78 \%$ ) The seasonal mortality rates from the apiaries with clinical signs of varroosis at V2 $(3.48 \%)$ and from the apiaries without any clinical signs at V2 (3.00\%) were not statistically different from the mean seasonal mortality of participating countries (i.e., $3.06 \%$ ).

AFB was clinically observed and confirmed in a small proportion of apiaries at V1 $(2.36 \%)$ and V2 $(1.88 \%)$. In these apiaries, the winter mortality rate was of $33.72 \%$ and the seasonal colony mortality rate of $12.56 \%$, respectively (Table III). Mortality rates of apiaries affected by AFB were higher and statistically different from the mean mortality of participating countries whether it was winter mortality (i.e., $12.71 \%$, $p=1 \cdot 10^{-14}$ ) or seasonal mortality (i.e., $3.09 \%$, $p=4 \cdot 10^{-9}$ ).

EFB was also clinically observed and confirmed in a small proportion of apiaries at V1 $(1.03 \%)$ and V2 $(1.05 \%)$. In these apiaries, the winter mortality rate was of $21.43 \%$ and the seasonal colony mortality rate of $18.82 \%$ (Table III). The seasonal mortality rate of apiaries affected by EFB was higher and statically different $\left(p=9 \cdot 10^{-9}\right)$ from the seasonal mean mortality of participating countries (i.e., $3.10 \%$ ).

\subsection{Multivariable analysis}

The synthetic variable environment with 16 categories was subdivided into four variables (FA, OR, TO, and FL) with two categories (i.e., "yes" or "no"). Therefore, 15 explanatory variables were statistically studied. The multivariable model was developed on a fixed sample of 2332 apiaries for the winter mortality and 2290 for the seasonal mortality. The two dependent variables (i.e., the two mortality rates) were analyzed separately. Eleven explanatory variables (the 15 variables except the participation to a common veterinary treatment, TO, chronic bee paralysis, and EFB) were kept for the multivariable model on winter mortality (Table IV). For the winter mortality, the clustering implemented on the diseases, the size of the operation and apiary, and the environment has produced three groups for disease (apiaries suffering at V1 from varroosis; from AFB; from nosemosis; without any disease), four groups for the size of the operation and apiary 

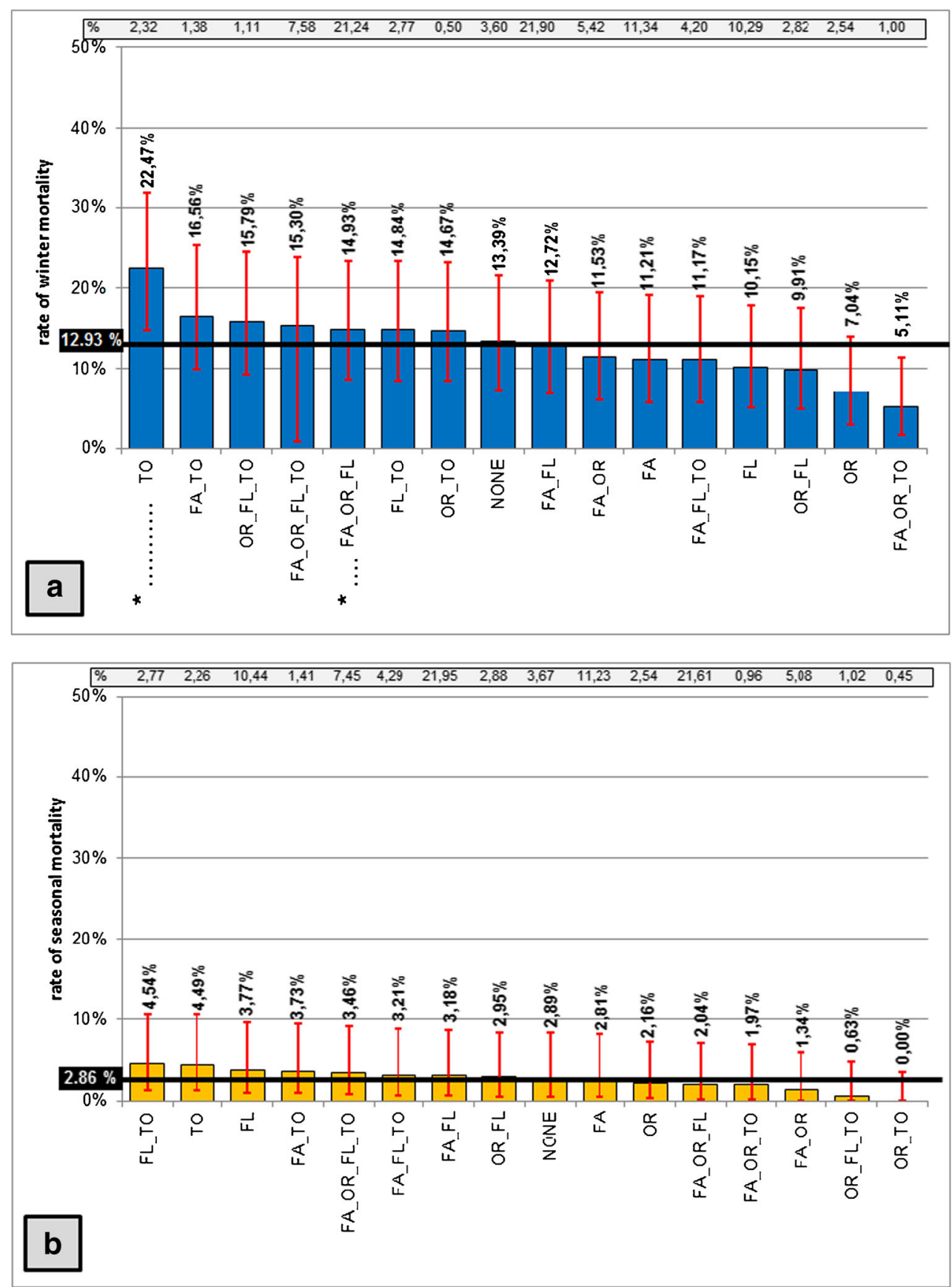

Figure 5. Mortality observed in the MSs taking part in EPILOBEE 2012-2013 according to the 16 different types of environment surrounding the apiary reported by the beekeepers and the bee inspectors. The proportion of each category is given on the top of the graph (\%): it was based on the 1808 apiaries studied for the winter mortality or on the 1772 studied for the seasonal mortality. FA farmland, $F L$ floral, $O R$ orchards, $T O$ towns. Each mortality rate was compared to the mean mortality of participating countries. The statistical differences are indicated with asterisks $\left(*=p<0.05,{ }^{*}=p<0.01 ; * * *=p<0.001\right)$. The red line segments represented the $95 \%$ confidence intervals. a Winter mortality. b Seasonal mortality. 
Table III. Winter and seasonal mortality rates related to the 12 variables studied in the univariate analysis and $95 \%$ CI.

\begin{tabular}{|c|c|c|c|c|c|}
\hline Factors & Categories & \begin{tabular}{|c|} 
Winter \\
mortality \\
rates (\%)
\end{tabular} & $\begin{array}{l}95 \% \text { confidence } \\
\text { intervals }\end{array}$ & $\begin{array}{l}\text { Seasonal } \\
\text { mortality } \\
\text { rates (\%) }\end{array}$ & $\begin{array}{l}95 \% \text { confidence } \\
\text { intervals }\end{array}$ \\
\hline \multicolumn{6}{|l|}{ Country } \\
\hline & Belgium & 30.64 & {$[21.81 ; 40.65]$} & 6.91 & {$[2.80 ; 13.78]$} \\
\hline & Denmark & 16.13 & {$[9.53 ; 24.83]$} & 1.74 & {$[0.17 ; 6.64]$} \\
\hline & England and Wales & 26.16 & {$[17.88 ; 35.90]$} & 8.74 & {$[4.02 ; 16.08]$} \\
\hline & Estonia & 21.05 & {$[13.54 ; 30.35]$} & 3.79 & {$[0.99 ; 9.63]$} \\
\hline & Finland & 20.71 & {$[13.25 ; 29.97]$} & 5.38 & {$[1.86 ; 11.79]$} \\
\hline & France & 13.58 & {$[7.55 ; 21.88]$} & 10.55 & {$[5.29 ; 18.29]$} \\
\hline & Germany & 12.48 & {$[6.72 ; 20.59]$} & 3.15 & {$[0.69 ; 8.73]$} \\
\hline & Greece & 7.56 & {$[3.22 ; 14.60]$} & 3.25 & {$[0.73 ; 8.88]$} \\
\hline & Hungary & 9.90 & {$[4.83 ; 17.50]$} & 1.81 & {$[0.19 ; 6.75]$} \\
\hline & Italy & 4.73 & {$[1.49 ; 10.92]$} & 3.29 & {$[0.75 ; 8.93]$} \\
\hline & Latvia & 18.32 & {$[11.29 ; 27.31]$} & 0.47 & {$[0.00 ; 4.52]$} \\
\hline & Lithuania & 5.06 & {$[1.68 ; 11.36]$} & 0.07 & {$[0.00 ; 3.76]$} \\
\hline & Poland & 17.48 & {$[10.61 ; 26.36]$} & 0.73 & {$[0.01 ; 4.99]$} \\
\hline & Portugal & 13.32 & {$[7.35 ; 21.58]$} & 3.28 & {$[0.75 ; 8.92]$} \\
\hline & Slovakia & 7.89 & {$[3.44 ; 15.02]$} & 0.61 & {$[0.00 ; 4.77]$} \\
\hline & Spain & 10.05 & {$[4.94 ; 17.68]$} & 6.54 & {$[2.57 ; 13.30]$} \\
\hline & Sweden & 26.65 & {$[18.30 ; 36.43]$} & 3.07 & {$[0.65 ; 8.62]$} \\
\hline \multicolumn{6}{|l|}{ Beekeeper age } \\
\hline & $<30$ & 14.40 & {$[8.18 ; 22.84]$} & 2.37 & {$[0.37 ; 7.60]$} \\
\hline & $30-45$ & 13.86 & {$[7.76 ; 22.21]$} & 2.43 & {$[0.39 ; 7.69]$} \\
\hline & $45-65$ & 10.93 & {$[5.57 ; 18.75]$} & 3.21 & {$[0.72 ; 8.82]$} \\
\hline & $>65$ & 14.69 & {$[8.40 ; 23.17]$} & 3.48 & {$[0.84 ; 9.20]$} \\
\hline \multirow{3}{*}{$\begin{array}{l}\text { Participation to a common } \\
\text { veterinary treatment }\end{array}$} & & & & & \\
\hline & No & 12.87 & {$[7.01 ; 21.05]$} & 3.94 & {$[1.07 ; 9.84\}$} \\
\hline & Yes & 12.78 & {$[6.94 ; 20.95]$} & 2.44 & {$[0.40 ; 7.70]$} \\
\hline \multicolumn{6}{|l|}{ Migration } \\
\hline & Yes & 14.47 & {$[8.23 ; 22.92]$} & 3.00 & {$[0.62 ; 8.52]$} \\
\hline & No & 10.41 & {$[5.19 ; 18.12]$} & 3.34 & {$[0.78 ; 9.00]$} \\
\hline \multicolumn{6}{|l|}{ Environment } \\
\hline & FA & 11.21 & {$[5.77 ; 19.08]$} & 2.81 & {$[0.54 ; 8.24]$} \\
\hline & $\mathrm{FL}$ & 10.15 & {$[5.01 ; 17.80]$} & 3.77 & {$[0.98 ; 9.61]$} \\
\hline & OR & 7.04 & {$[2.89 ; 13.94]$} & 2.16 & {$[0.30 ; 7.28]$} \\
\hline & TO & 22.47 & {$[14.73 ; 31.91]$} & 4.49 & {$[1.36 ; 10.60]$} \\
\hline & FA_FL & 12.72 & {$[6.90 ; 20.87]$} & 3.18 & {$[0.70 ; 8.78]$} \\
\hline & FA_OR & 11.53 & {$[6.01 ; 19.46]$} & 1.34 & {$[0.08 ; 6.00]$} \\
\hline & FA_TO & 16.56 & {$[9.88 ; 25.32]$} & 3.73 & {$[0.96 ; 9.55]$} \\
\hline & FL_TO & 14.84 & {$[8.52 ; 23.35]$} & 4.54 & {$[1.39 ; 10.66]$} \\
\hline & OR_FL & 9.91 & {$[4.84 ; 17.91]$} & 2.95 & {$[0.60 ; 8.45]$} \\
\hline & OR_TO & 14.67 & {$[8.39 ; 23.15]$} & 0.00 & {$[0.00 ; 3.62]$} \\
\hline & FA_FL_TO & 11.17 & {$[5.74 ; 19.03]$} & 3.21 & {$[0.72 ; 8.82]$} \\
\hline & FA_OR_FL & 14.93 & {$[8.59 ; 23.45]$} & 2.04 & {$[0.26 ; 7.10]$} \\
\hline & FA_OR_TO & 5.11 & {$[1.71 ; 11.43]$} & 1.97 & {$[0.23 ; 6.99]$} \\
\hline & OR_FL_TO & 15.79 & {$[9.27 ; 24.44]$} & 0.63 & {$[0.00 ; 4.81]$} \\
\hline & FA_OR_FL_TO & 15.30 & {$[8.88 ; 23.88]$} & 3.46 & {$[0.83 ; 9.17]$} \\
\hline & NONE & 13.39 & {$[7.40 ; 21.66]$} & 2.89 & {$[0.58 ; 8.36]$} \\
\hline
\end{tabular}


Table III. (Continued)

\begin{tabular}{|c|c|c|c|c|c|}
\hline \multicolumn{6}{|l|}{ Apiary size } \\
\hline & $\leq 5$ colonies & 19.69 & {$[12.41 ; 28.84]$} & 4.49 & {$[1.36 ; 10.60]$} \\
\hline & $6-10$ colonies & 18.10 & {$[11.11 ; 27.06]$} & 3.70 & {$[0.95 ; 9.51]$} \\
\hline & $11-20$ colonies & 14.32 & {$[8.12 ; 22.74]$} & 3.61 & {$[0.91 ; 9.38]$} \\
\hline & $21-50$ colonies & 12.69 & {$[6.87 ; 20.84]$} & 2.67 & {$[0.48 ; 8.04]$} \\
\hline & $>50$ colonies & 7.71 & {$[3.32 ; 14.79]$} & 2.50 & {$[0.42 ; 7.79]$} \\
\hline \multicolumn{6}{|c|}{ Size of the operation } \\
\hline & $\leq 50$ colonies & 15.84 & {$[9.30 ; 24.50]$} & 3.17 & {$[0.70 ; 8.76]$} \\
\hline & 51 - 100 colonies & 9.94 & {$[4.86 ; 17.55]$} & 1.78 & {$[0.18 ; 6.70]$} \\
\hline & $101-150$ colonies & 9.50 & {$[4.55 ; 17.01]$} & 1.79 & {$[0.18 ; 6.72]$} \\
\hline & 151 - 200 colonies & 10.49 & {$[5.22 ; 18.17]$} & 4.06 & {$[1.13 ; 10.01]$} \\
\hline & $201-300$ colonies & 5.30 & {$[1.82 ; 11.68]$} & 2.19 & {$[0.31 ; 7.33]$} \\
\hline & $>300$ colonies & 8.12 & {$[3.60 ; 15.31]$} & 5.69 & {$[2.05 ; 12.20]$} \\
\hline \multicolumn{6}{|c|}{ Varroosis at V1 } \\
\hline & Not suffering & 11.67 & {$[6.11 ; 19.63]$} & & \\
\hline & Suffering & 19.15 & {$[11.97 ; 28.24]$} & & \\
\hline \multicolumn{6}{|c|}{ Varroosis at V2 } \\
\hline & Not suffering & & & 3.00 & {$[0.62 ; 8.52]$} \\
\hline & Suffering & & & 3.48 & {$[0.84 ; 9.20]$} \\
\hline \multicolumn{6}{|c|}{ Chronic bee paralysis at V1 } \\
\hline & Not suffering & 12.70 & {$[6.88 ; 20.85]$} & & \\
\hline & Suffering & 18.92 & {$[11.78 ; 27.98]$} & & \\
\hline \multicolumn{6}{|c|}{ Chronic bee paralysis at V2 } \\
\hline & Not suffering & & & 3.05 & {$[0.64 ; 8.59]$} \\
\hline & Suffering & & & 4.00 & {$[1.10 ; 9.93]$} \\
\hline \multicolumn{6}{|l|}{$\overline{A F B}$ at $V 1$} \\
\hline & Not suffering & 12.20 & {$[6.51 ; 20.26]$} & & \\
\hline & Suffering & 33.72 & {$[24.57 ; 43.86]$} & & \\
\hline \multicolumn{6}{|l|}{ AFB at $\mathrm{V} 2$} \\
\hline & Not suffering & & & 2.88 & {$[0.57 ; 8.34]$} \\
\hline & Suffering & & & 12.56 & {$[6.72 ; 20.69]$} \\
\hline \multicolumn{6}{|c|}{ Nosemosis at V1 } \\
\hline & Not suffering & 12.64 & {$[6.84 ; 20.78]$} & & \\
\hline & Suffering & 21.77 & {$[14.14 ; 31.14]$} & & \\
\hline \multicolumn{6}{|c|}{ Nosemosis at V2 } \\
\hline & Not suffering & & & 3.12 & {$[0.68 ; 8.69]$} \\
\hline & Suffering & & & 2.57 & {$[0.44 ; 7.89]$} \\
\hline \multicolumn{6}{|l|}{ EFB at $V 1$} \\
\hline & Not suffering & 12.65 & {$[6.84 ; 20.79]$} & & \\
\hline & Suffering & 21.43 & {$[13.85 ; 30.77]$} & & \\
\hline \multicolumn{6}{|l|}{ EFB at V2 } \\
\hline & Not suffering & & & 2.93 & {$[0.59 ; 8.72]$} \\
\hline & Suffering & & & 18.82 & {$[11.70 ; 27.87]$} \\
\hline
\end{tabular}

Gray cells mean that the calculation of mortality rates was not performed (e.g., varroosis at V1 was analyzed only for the winter mortality as response variable. With the seasonal mortality as response variable, no seasonal mortality rate has been calculated)

(operation $\leq 50$ and apiary $\leq 20$ [size 1]; operation $\leq 50$ and apiary between 21 and 50 [size 2]; operation between 51 and 300 and apiary $>50$ [size 3]; operation $>300$ and apiary $>50$ [size 
Table IV. Explanatory variables to be included in the multivariable model for the winter mortality (2332 apiaries) and the seasonal mortality (2290 apiaries).

\begin{tabular}{|c|c|c|c|c|}
\hline \multirow[b]{2}{*}{ Explanatory variables } & \multicolumn{2}{|c|}{ Winter mortality } & \multicolumn{2}{|c|}{ Seasonal mortality } \\
\hline & $p$ value & $\begin{array}{l}\text { Inclusion in } \\
\text { the model }\end{array}$ & $p$ value & $\begin{array}{l}\text { Inclusion in } \\
\text { the model }\end{array}$ \\
\hline Country & $1.36 \cdot 10^{-26}$ & Included & $6.99 \cdot 10^{-23}$ & Included \\
\hline Beekeeper age & $1.64 \cdot 10^{-4}$ & Included & 0.77 & Not included \\
\hline $\begin{array}{l}\text { Participation to a common veterinary } \\
\text { treatment }\end{array}$ & 0.31 & Not Included & $4.69 \cdot 10^{-9}$ & Included \\
\hline Migration & $6.75 \cdot 10^{-3}$ & Included & $3.71 \cdot 10^{-7}$ & Included \\
\hline FA & 0.13 & Included & 0.09 & Included \\
\hline OR & $1.77 \cdot 10^{-8}$ & Included & 0.53 & Not included \\
\hline $\mathrm{FL}$ & $7.92 \cdot 10^{-3}$ & Included & 0.03 & Included \\
\hline TO & 0.67 & Not included & 0.61 & Not included \\
\hline Apiary size & $5.00 \cdot 10^{-29}$ & Included & $5.55 \cdot 10^{-12}$ & Included \\
\hline Size of the operation & $9.59 \cdot 10^{-3}$ & Included & $6.47 \cdot 10^{-9}$ & Included \\
\hline Varroosis at V1 & $9.74 \cdot 10^{-6}$ & Included & & \\
\hline Varroosis at V2 & & & 0.42 & Not included \\
\hline Chronic bee paralysis at V1 & 0.96 & Not included & & \\
\hline Chronic bee paralysis at V2 & & & 0.81 & Not included \\
\hline $\mathrm{AFB}$ at $\mathrm{V} 1$ & $7.74 \cdot 10^{-10}$ & Included & & \\
\hline $\mathrm{AFB}$ at $\mathrm{V} 2$ & & & $5.38 \cdot 10^{-17}$ & Included \\
\hline Nosemosis at V1 & $1.3710^{-3}$ & Included & & \\
\hline Nosemosis at V2 & & & 0.56 & Not included \\
\hline $\mathrm{EFB}$ at $\mathrm{V} 1$ & 0.30 & Not included & & \\
\hline $\mathrm{EFB}$ at $\mathrm{V} 2$ & & & $1.66 \cdot 10^{-5}$ & Included \\
\hline
\end{tabular}

The variables were included in the multivariable model if $p$ value $<0.20$. Gray cells mean that the explanatory variable placed on the first column was not statistically analyzed (for the winter mortality, varroosis at V1 was statistically analyzed, while for the seasonal mortality, varroosis at V2 was analyzed) 
4]), and five groups for environment (OR; FA and FL; FA; FL; no environment reported).

These three new synthetic variables (disease, size of the operation and apiary, and environment) were included in the model together with variables already selected (beekeeper age and migration) in order to select the best combination of the explanatory variables. The qselection procedure selected the size of the operation and apiary and diseases. The order 2 interaction between the variables was significant according to the backward procedure. The effect of the country being studied separately as a random effect (Figure 2), the risk factors with significant effects were common to all MSs and can be modeled as

Mortality expected (size, disease $)=100 \times \exp \left(\right.$ GRM-0.08 (size 2) $-0.32_{(\text {size 3) }}-0.24_{(\text {size } 4)}+0.52_{(\text {varroosis })}$ $+0.79_{(\mathrm{AFB})}+1.27_{\text {(nosemosis) }}-0.01_{\text {(size 2, varroosis })}+0.64_{(\text {size } 2, \mathrm{~A} \mathrm{FB})}-1.09_{(\text {size } 2, \text { nosemosis })}+0.29_{(\text {size } 3 \text {, varroosis })}$ $\left.+0.26_{(\text {size } 3, \mathrm{AFB})}-0.54_{\text {(size } 3, \text { nosemosis })}+0.00_{(\text {(size } 4 \text {, varroosis) }}-0.28_{(\text {size } 4, \text { nosemosis })}\right)$

with group reference mortality (GRM) equals -2.04 for a apiary in size 1 without any disease at V1.

By considering a group of a size 1 apiary without any disease at V1 as GRM, the effect of the size component seemed protective (without any interaction with the disease component): the coefficients were negative for the size 2-size 3size 4 (respectively, $-0.08,-0.32$, and -0.24 ) and led to obtain (for an apiary without any disease) a lower winter mortality rate: $11.97 \%$ for a size 2 apiary; $9.42 \%$ for a size 3 apiary; and $10.20 \%$ for a size 4 apiary instead of $12.97 \%$ (size 1 apiary). This trend is also noted considering an apiary suffering from varroosis at V1 (19.94 \% for a size 2 apiary; $21.17 \%$ for a size 3 apiary; $17.15 \%$ for a size 4 apiary instead of $21.81 \%$ for a size 1 apiary) or nosemosis at V1 (Table V). The analysis of these coefficients was conducted to obtain the same conclusions as the ones of the univariate analysis: the winter mortality was less important considering a bigger size of operations and apiary. However, this protective effect was lighter compared to the effects studied below.

By considering again a group of a size 1 apiary without any disease at V1 as GRM, the effect of the disease component seemed aggravating (without any interaction with the size component). The coefficients were positive for varroosis, $\mathrm{AFB}$, and nosemosis (respectively, $+0.52,+0.79$, and +1.27 ) and led to obtain (for a size 1 apiary) a higher winter mortality rate: $21.81 \%$ for an apiary suffering from varroosis at V1, $28.57 \%$ for an apiary suffering from AFB at V1, and $46.18 \%$ for an apiary suffering from nosemosis at V1 instead of $12.97 \%$ for an apiary without any disease at V1. This trend is also noted considering a size 2, a size 3 , or a size 4 apiary (Table V). These coefficients showed that according to the disease affecting the apiary at V1, the winter mortality was more or less important, compared to an apiary without any disease. This aggravating effect was stronger than the one (protective) generated by the size component, as mentioned earlier.

Combining the effect of the size component and the disease component, the order 2 interaction was significant (backward procedure). By considering a group of a size 1 apiary without any disease at V1 as GRM, an apiary suffering from nosemosis at V1 obtained finally the smallest winter mortality rate with a size 2 apiary (the coefficient for the size $2 \times$ nosemosis interaction was smaller than both coefficients of the size $3 \times$ nosemosis and the size $4 \times$ nosemosis interactions). An apiary suffering from AFB at V1 obtained the highest winter mortality rate with a size 2 apiary (highest coefficient for the size $2 \times$ AFB interaction). Lastly, an apiary suffering from varroosis at V1 obtained the lowest winter mortality rate with a size 4 apiary. Indeed, the addition of the coefficients led to obtain the smallest final coefficient for a size 4 apiary $(+0.52=0.52$ [size 1 ; varroosis]; $+0.52-0.08-0.01=0.43$ [size 2 ; varroosis]; $+0.52-0.32+0.29=0.49$ [size 3 ; varroosis]; $+0.52-0.24+0.00=0.28$ [size 4 ; varroosis] - Table V).

To summarize, the highest winter mortality rate $(50.02 \%)$ would be observed in the theoretical 
Table V. Winter mortalities calculated according to the multivariable model.

\begin{tabular}{|c|c|c|}
\hline Size & Disease & Winter mortality expected \\
\hline 1 & Not suffering & $12.97 \%$ \\
\hline 1 & Varroosis at V1 & $21.81 \%$ \\
\hline 1 & AFB at V1 & $28.57 \%$ \\
\hline 1 & Nosemosis at $\mathrm{V} 1$ & $46.18 \%$ \\
\hline 2 & Not suffering & $11.97 \%$ \\
\hline 2 & Varroosis at V1 & $19.94 \%$ \\
\hline 2 & AFB at V1 & $50.02 \%$ \\
\hline 2 & Nosemosis at V1 & $14.33 \%$ \\
\hline 3 & Not suffering & $9.42 \%$ \\
\hline 3 & Varroosis at V1 & $21.17 \%$ \\
\hline 3 & AFB at $\mathrm{V} 1$ & $26.91 \%$ \\
\hline 3 & Nosemosis at V1 & $19.54 \%$ \\
\hline 4 & Not suffering & $10.20 \%$ \\
\hline 4 & Varroosis at V1 & $17.15 \%$ \\
\hline 4 & $\mathrm{AFB}$ at $\mathrm{V} 1$ & \\
\hline 4 & Nosemosis at V1 & $27.45 \%$ \\
\hline
\end{tabular}

The red line indicates the highest mortality and the green one the lowest mortality. Gray cell means that the database did not store any size 4 apiary suffering from AFB at V1. Size 1: operation $\leq 50$ colonies and apiary $\leq 20$ colonies; size 2 : operation $\leq 50$ and apiary between 21 and 50; size 3: operation between 51 and 300 and apiary $>50$; size 4: operation $>300$ and apiary $>50$

case of a size 2 apiary suffering clinically from $\mathrm{AFB}$ at $\mathrm{V} 1$; the lowest winter mortality rate $(9.74 \%)$ would be observed in the theoretical case of a size 3 apiary without any disease at V1 (Table V).

The variables beekeeper age, OR, TO, varroosis, chronic bee paralysis, and nosemosis were not kept for the multivariable model on the seasonal mortality (Table IV). For the seasonal mortality, the clustering was also implemented on the diseases, the size of the operation, and apiary and the environment. For the size of the operation and apiary, the groups were the same as previously described. Two groups were defined for disease (apiaries suffering at V2 from a disease or without any disease) and four groups for environment (FA_FL; FA; FL; no environment reported). 
These two synthetic variables were included in the model together with participation to a common veterinary treatment and migration. The qselection procedure selected the size of operation and apiary, diseases, and participation to a common veterinary treatment. The backward procedure kept the following components for the analysis: the size of the operation and apiary, diseases, participation to a common veterinary treatment, and the order 2 interaction between the size of the operation and apiary and diseases. The risk factors with significant effects were common to all MS and can be modeled as

Mortality expected $_{(\text {size, disease, treat })}=100 \times \exp \left(\mathrm{GRM}+0.11_{(\text {size } 2)}-0.16_{(\text {size } 3)}+0.24_{(\text {size } 4)}+1.31_{(\text {suffering })}\right.$ $\left.-0.59_{\text {(treat }=\text { yes) }}+0.28_{(\text {size } 2, \text { suffering })}-+0.09_{(\text {size } 3, \text { suffering })}-1.51_{(\text {(size } 4, \text { suffering })}\right)$

with GRM equals -3.48 for a size 1 apiary without any disease at V2 and any common veterinary treatment.

By considering a group of a size 1 apiary without any disease at V2, and any common veterinary treatment as GRM, the effect of the size component seemed variable according to the size of the operation and livestock (without any interaction with the disease and common veterinary treatment components): the size 3 had a protective effect (negative coefficient, -0.16 ) and the sizes 2 and 4 had an aggravating effect (positive coefficients, +0.11 and +0.24 , respectively). These coefficients led to obtain (for an apiary without any disease and any common veterinary treatment) the lowest seasonal mortality rate for a size 3 apiary (3.43\% for a size 2 apiary; $2.61 \%$ for a size 3 apiary; $3.90 \%$ for a size 4 apiary instead of $3.07 \%$ for a size 1 apiary). This trend is also noted considering a size 1 apiary, without any disease at V2 and taking part to a common veterinary treatment (1.90\% for a size 2 apiary; $1.45 \%$ for a size 3 apiary; $2.16 \%$ for a size 4 apiary instead of $1.7 \%$ for a size 1 apiary-Table VI).

By considering again a group of a size 1 apiary without any disease at V2, and any common veterinary treatment as GRM, the effect of the disease component seemed aggravating (without any interaction with the size and common veterinary treatment components): the coefficient was positive $(+1.31)$ and led to obtain (for a size 1 apiary without any common veterinary treatment) a higher seasonal mortality rate: $11.37 \%$ from an apiary suffering from any disease instead of $3.07 \%$ (apiary without any disease). The effect of the common veterinary treatment component seemed protective (without any interaction with the disease and common veterinary treatment components): the coefficient was negative $(-0.59)$ and conducted to get (for a size 1 apiary without any disease) a lower seasonal mortality rate: $1.70 \%$ from an apiary which took part to a common veterinary treatment instead of $3.07 \%$ (apiary without any common veterinary treatment-Table VI). Analyzing the variation between these seasonal mortality rates, the effect of the disease component is stronger than the common veterinary treatment component.

Combining the effect of the three components, the order 2 interaction between the size component and the disease component was significant (backward procedure). By considering again, a group of a size 1 apiary without any disease at $\mathrm{V} 2$, and any common veterinary treatment as GRM, an apiary suffering from any disease at V2, without any common veterinary treatment, got finally the smallest winter mortality rate with a size 4 apiary. Indeed, combining the the addition of the coefficients led to obtain the smallest final coefficient for a size 4 apiary $(+1.31=1.31$ [size 1 ; suffering; treat $=$ no]; $+1.31+0.11+0.28=1.70$ [size 2; suffering; treat $=$ no]; +1.31 $-0.16+0.09=0.49$ [size 3; suffering; treat $=$ no]; $+1.31+0.24-1.51=0.04$ [size 4 ; suffering; treat $=$ no] - Table VI). The same tendency was notable taking into account an apiary suffering from any disease and taking part to common veterinary treatment.

To summarize, the highest seasonal mortality rate $(16.80 \%)$ would be observed in the 
Table VI. Seasonal mortalities calculated according to the multivariable model.

\begin{tabular}{|c|c|c|c|}
\hline Size & Disease & $\begin{array}{l}\text { Participation to a common veterinary } \\
\text { treatment }\end{array}$ & Seasonal mortality expected \\
\hline 1 & Not suffering & No & $3.07 \%$ \\
\hline 1 & Suffering & No & $11.37 \%$ \\
\hline 1 & Not Suffering & Yes & $1.70 \%$ \\
\hline 1 & Suffering & Yes & $6.30 \%$ \\
\hline 2 & Not suffering & No & $3.43 \%$ \\
\hline 2 & Suffering & No & $16.80 \%$ \\
\hline 2 & Not Suffering & Yes & $1.90 \%$ \\
\hline 2 & Suffering & Yes & $9.31 \%$ \\
\hline 3 & Not suffering & No & $2.61 \%$ \\
\hline 3 & Suffering & No & $10.60 \%$ \\
\hline 3 & Not Suffering & Yes & $1.45 \%$ \\
\hline 3 & Suffering & Yes & $5.88 \%$ \\
\hline 4 & Not suffering & No & $3.90 \%$ \\
\hline 4 & Suffering & No & $3.19 \%$ \\
\hline 4 & Not Suffering & Yes & $2.16 \%$ \\
\hline 4 & Suffering & Yes & $1.77 \%$ \\
\hline
\end{tabular}

The red line indicates the highest mortality and the green one the lowest mortality. Size 1: operation $\leq 50$ colonies and apiary $\leq 20$ colonies; size 2: operation $\leq 50$ and apiary between 21 and 50; size 3: operation between 51 and 300 and apiary >50; size 4: operation $>300$ and apiary $>50$

theoretical case of a size 2 apiary without any common veterinary treatment suffering clinically from one disease at V2; the lowest seasonal mortality rate $(1.45 \%)$ would be observed in a size 3 apiary with a common veterinary treat and without any disease at V2 (Table VI).

\section{DISCUSSION}

Using multivariable Poisson regression models, this study has provided statistical evidences that the size of the operation and apiary and the clinically detected varroosis, AFB, and nosemosis during the autumn 2012 were 
significant risk indicators affecting the mortality of honeybee colonies during the winter of 20122013 in Europe. For any clinical disease detected, the size of the operation and apiary and the nonparticipation to a common veterinary treatment were the risk indicators having a significant effect on honeybee colony mortality during the season in Europe. The country effect has been studied as a random effect, with a strong effect on both mortalities.

\subsection{Colony mortality rates}

Different winter colony losses have been reported in European countries and outside Europe in various publications (Genersch et al. 2010; Potts et al. 2010; Spleen et al. 2013). The empirical threshold of $10 \%$ was considered acceptable in this paper for European winter honeybee colony mortality by the EPILOBEE consortium. Indeed, in some areas of Europe and other parts of the world, higher or lower mortality rates can be considered as bearable by beekeepers and scientists (for the discussion refer to Chauzat et al. (2014a, b)).

Significant regional differences in colony losses were also observed. Weather variables such as temperature, humidity, and wind speed might have influenced winter colony losses during the winter 2012-2013 that was particularly long and harsh across Europe. A consistent finding within the US loss data was that beekeepers in northern states lose more colonies than those in southern states (Steinhauer et al. 2014; Lee et al. 2015). However, the role of climate in the winter colony mortality should be further balanced with other risk factors such as exposure to pesticides, food availability, and beekeeping practices.

Monitoring is a regular, repetitive, and intermittent series of measurements designed to detect changes in the health status of defined populations (Lee et al. 2015). Apiary inspections are an example of monitoring as implemented in EPILOBEE. However, this approach is time consuming and organization and centralization are needed. As example, EPILOBEE was run for only 2 years. On the other hand, questionnaires are relatively easy to conduct but are prone to biases (Lee et al. 2015). In surveillance system where honeybee colony losses are based on voluntary answer from beekeepers in questionnaires, it is highly understandable that beekeepers with high mortality rates may be keen on declaring mortalities, more than beekeepers without any problems. The real honeybee colony situation might be over- or underrepresented. For example, COLOSS questionnaire on honeybee colony losses was based on voluntary answer from beekeepers implemented with different survey modes according to participating countries including census models, selfselected samples, and randomly selected samples (vanderZee et al. 2014). Different types of surveillance have pros and cons (nicely reviewed in Lee et al. (2015)). To ensure sustainability in colony mortality surveillance, one might consider taking advantage of both approaches (onsite investigations and questionnaires) by using the less expensive means of survey (questionnaires) distributed according to a sampling plan to avoid bias and be representative of the population.

In the present statistical analysis, the mortality rates of groups of apiaries (i.e., group of apiaries from Hungary, group of apiaries managed by a beekeeper between 45 and 65 years old, group of apiaries managed by beekeepers owning between 51 and 100 colonies ....) were not weighted by the size of the apiaries composing these groups. However, earlier in the present paper, a weighed calculation was performed to calculate the mean mortality of the participating countries: in this case, several groups of apiaries were taken into account; therefore, it was possible to weight the calculation by the number of apiaries of each group (i.e., each category). However, the mortality rates (winter and seasonal) calculated in this paper did not differ drastically from the rates described in previous reports (Chauzat et al. 2014a, b; Laurent et al. 2015).

In EPILOBEE, the number of apiaries under study was equally distributed in each MS (Figure 1). This should be put in perspective with the beekeeping demography in Europe, where the numbers of honeybee colonies were higher in the MSs located in some southern countries (Greece, Italy, and Spain) compared to the MSs located in Northern Europe (Chauzat et al. 2013).

Significant difference in winter mortality compared to the mean winter mortality of participating 
countries $(12.70 \%)$ was observed for beekeepers over 65 years (winter mortality rate $14.69 \%$ ) and for beekeepers between 45 and 65 years (10.93\% - unpublished data). It should be noted that the overall apiarist population in Europe has always been elderly especially for hobbyists. It has been largely reported that very few young beekeepers started new operations, particularly in the professional section. This variable of age was statistically linked to the size of the apiaries (unpublished data). Elderly beekeepers usually possessed a few honeybee colonies in the backyard as they always had. Once they ceased the beekeeping activity, colonies were not taken over by a younger beekeeper. This tendency should however be nuanced by a new trendy "urban beekeeping" movement rising in Europe and the USA that attracts many new people, preferably young, who are still not familiar with all the demands for keeping healthy bees. Usually, these new beekeepers have started beekeeping activities lacking basic skills and knowledge background.

In EPILOBEE, higher winter mortalities were observed in small apiaries. This was related to the status of the beekeepers. Although the definition of professional beekeeping was different in the different MSs (Chauzat et al. 2013), apiaries with a high number of colonies were mostly owned by professional beekeepers $\left(p=7.91 \cdot 10^{-195}\right.$, unpublished data) who rely on beekeeping activity for their main income. Therefore, several assumptions could be formulated to explain the better survival of honeybee colonies in these large apiaries: the professionals had a better knowledge on beekeeping practices (e.g., preparation of colonies for winter), disease detection, and management; they may have applied better and earlier prophylactic measures to colonies. The lower seasonal mortality rates were also associated with lower mortalities in migratory apiaries (univariate analysis). It is known that professional beekeepers move more frequently their hives targeting the nectar flows. Indeed, other publications have shown that food resources may lack qualitatively and quantitatively in some areas at some points in the year (reviewed in Decourtye et al. (2010)). EPILOBEE was an observational surveillance system that helped in obtaining information on risk indicators affecting mortality in real-world complex systems. However, all these hypotheses should be fully tested in dedicated experimental protocols (explicative epidemiology) to validate the risk indicators and clarify any potential causality (Lee et al. 2015).

In EPILOBEE, the environment was assessed by beekeepers and the bee inspectors. It was not accurately measured by any geographical system. Therefore, results should be taken with caution as they might not be really representative of the landscape. Again, EPILOBEE being a descriptive epidemiological program, conclusions should not be drawn beyond the limits of the protocol. To better study the environment, an experimental epidemiological protocol could be specifically designed to collect more robust data allowing strong correlations and conclusions.

Several drivers of honeybee loss have been proposed (Goulson et al. 2015), but to date, there is little consensus on which driver or combination of drivers are responsible for observed declines in Europe except for the mite Varroa destructor, which clearly plays a central role, because it infests virtually every honey bee colony in Europe (Potts et al. 2010).

\subsection{Disease at apiary level}

The clinical prevalence was low for all the diseases considered in EPILOBEE. Three diseases had a statistical impact on honeybee colony survival (winter and seasonal). Varroosis was reported in nearly all the MSs and significantly reduced the chance for a colony to survive (univariate analysis and multivariable model) as shown many times (Pohorecka et al. 2014). Indeed, the apiaries affected by varroosis at V1 experienced higher winter mortality than the apiaries free of varroosis. However, it should be noted that the absence of varroosis did not mean the absence of Varroa mite carriage. Only on very rare cases, colonies without any $V$. destructor mites can be found. Honeybee colony survival to winter was also negatively impacted by AFB. This disease has been the subject of many studies particularly to understand the variability in virulence, transmission routes, and strain traceability (Schaefer et al. 2014). However, epidemiological studies are not frequent to assess the laboratory 
test determined prevalence of the disease at European level. EPILOBEE data confirmed the risk impact of these diseases in the field at their clinically observable stage. Nevertheless, the regulation of AFB implemented at national level could explain the significant effect of AFB on colony mortality and the subsequent low level of clinical prevalence recorded in the field as it includes notification of outbreak and subsequent culling of affected apiaries. The third disease with a significant impact on honeybee mortality was nosemosis. The disease has been the subject of many debates in the last years, particularly because of the detection of $N$. ceranae on the European honeybee (Higes et al. 2010).

It should be emphasized that the substantial amount of data gathered throughout EPILOBEE on various topics (use of veterinary treatments, the beekeeping context, colony management...) should be further analyzed to possibly get statistical correlations between the colony losses and some other risk factors. In the future, the statistical analysis should also include the colony and the apiary as two epidemiological levels. The data collected during 2 years should be included in the analysis. It should also be highlighted that such an extended first program led to some setbacks in the implementation of the standardized and common protocol in the participating countries. Representativeness was a key to the program and all the adjustments were made to obtain random sampling as representative as possible of the national situations despite the lack of national coverage in some countries. Moreover, random sampling was based on the list of beekeepers registered in each country and not on the total population of beekeepers which was not known in all participating countries. Results should be interpreted bearing all these information in mind.

\section{CONCLUSIONS}

The objective of EPILOBEE was to obtain a state of play on the colony mortality in Europe and some knowledge on the health of colonies. This first active pan-European descriptive program allowed the setup of epidemiological standardized methods in the MSs taking part in EPILOBEE. The active surveillance programs were adapted in each MS taking into account the national peculiarities. European and national surveillance systems benefited from this experience in the field of honeybee health.

In nine MS (Belgium, Denmark, England and Wales, Estonia, Finland, France, Latvia, Poland, and Sweden), the winter mortality rates were higher and statistically different from the empirical and acceptable level of $10 \%$ adopted here. In four countries (Greece, Italy, Lithuania, and Slovakia), the mortality rates were lower and statistically different from this threshold. The size of the operation and apiary and the clinically detected varroosis, $\mathrm{AFB}$, and nosemosis during the autumn 2012 were significant risk indicators affecting the survival of honeybee colonies during the winter of 2012-2013 in Europe. The country effect had a strong effect on both mortalities (winter and seasonal).

This descriptive program, EPILOBEE, was a required first step to facilitate future implementation of projects (e.g., explanatory studies) studying other risk factors affecting colony health. For example, the study on potential causes such as multiple or co-exposure to pesticides (e.g., insecticides, fungicides, and acaricides), infectious agents, and food intakes, either on their own or in combination, could be integrated in future explanatory studies. Harmonization in the methodology will be fundamental in further surveillance programs. Long-term collection of data on colony mortality would enable to obtain a representative overview on honeybee colony mortality in Europe.

\section{ACKNOWLEDGMENTS}

This project has been co-funded by the European Commission together with each member state taking part in EPILOBEE and ANSES through the EU RL for honeybee health. This program involved thousands of different stakeholders: beekeepers, veterinarians, bee inspectors, scientists, laboratories, and administrations. The EU RL for honeybee health wishes to thank all participants for their substantial involvement in the successful implementation of EPILOBEE.

Indicateurs de risque affectant la survie des colonies d'abeilles en Europe: une année de surveillance 
santé des abeilles / EPILOBEE / étude épidémiologique / mortalité hivernale / mortalité saisonnière

\section{Risikofaktoren für das Überleben von Honigbienenvölkern in Europa: Ergebnisse einer einjährigen Monitoringstudie}

Honigbienen-Gesundheit / EPILOBEE / epidemiologische Überwachung / Wintermortalität / saisonale Mortalität

\section{REFERENCES}

Aizen, M.A., Harder, L.D. (2009) The Global Stock of Domesticated Honey Bees Is Growing Slower Than Agricultural Demand for Pollination. Curr. Biol. 19, 915-8. doi:10.1016/j.cub.2009.03.071

Charrière, J.-D., Neumann, P. (2010) Surveys to estimate winter losses in Switzerland. J. Apic. Res. Bee World 49(1), 123-132

Chauzat, M.P., Cauquil, L., Roy, L., Franco, S., Hendrikx, P., et al. (2013) Demographics of the European beekeeping industry. PLoS One 8 (11), 1-12

Chauzat, M.P., Laurent, M., Rivière, M.P., Saugeon, C., Hendrikx, P., et al. (2014a) EPILOBEE. A panEuropean epidemiological study on honeybee colony losses 2012-2013, EURL for honeybee health, Sophia-Antipolis, pp. 1-32

Chauzat, M.P., Laurent, M., Rivière, M.P., Saugeon, C., Hendrikx, P., et al. (2014b) A pan-European surveillance programme on honey-bee colony mortalities. OIE Bull. 2014, 69-70

Commission E (2011) Commission implementing decision of 21 December 2011 concerning the adoption of a financing decision to support voluntary surveillance studies on honeybee colony losses. Official Journal of the European Union L343, 119.

Commission E (2012) Commission implementing decision $2012 / 362$ concerning a financial contribution by the Union to certain Member States to support voluntary surveillance studies on honeybee colony losses. Off. J. Eur. Union L 176, 4

Decourtye, A., Mader, E., Desneux, N. (2010) Landscape enhancement of floral resources for honey bees in agro-ecosystems. Apidologie 41, 264-277

EURL (2011) Guidelines for a European project on honeybee colony losses, p. 34. European Union, Brussels

Garin, E., Ribière-Chabert, M., Laurent, M., Hendrikx, P., Chauzat, M.P. (2014) When epidemiology meets apidology: A pan European surveillance program on honeybee colony losses (Apis mellifera), Society for veterinary epidemiology and preventive medicine, 2628th March 2014, Dublin, pp. 247-259

Genersch, E., Von der Ohe, W., Kaatz, H.H., Schroeder, A., Otten, C., et al. (2010) The German bee monitoring project: a long term study to understand periodically high winter losses of honey bee colonies. Apidologie 41, 332-352

Goulson, D., Nicholls, E., Botias, C., Rotheray, E.L. (2015) Bee declines driven by combined stress from parasites, pesticides, and lack of flowers. Science 347 (6229), 10

Greenacre, M.J. (1984) Theory and applications of correspondence analysis. Academic, London

Head K., Williams, G.R., Shutler, D., Colwell, M., BurgherMacLellan, K.L. et al. (2010) 2010 Newfoundland and Labrador Honey Bee Disease Survey, pp. 1-23

Hendrikx, P., Debin, M., Chauzat, M.P. (2010) Bee mortality and bee surveillance in Europe, EFSA Report, pp. 278

Higes, M., Martin-Hernandez, R., Meana, A. (2010) Nosema ceranae in Europe: an emergent type C nosemosis. Apidologie 41, 375-392

Josse, J., Chavent, M., Liquet, B., Husson, F. (2012) Handling missing values with Regularized Iterative Multiple Correspondence Analysis. J. Classif. 29(1), 91116

Laurent, M., Hendrikx, P., Ribière-Chabert, M., Chauzat, M.P. (2015) EPILOBEE - A pan-European epidemiological study on honeybee colony losses 2012-2014, p. 44. European Union, Brussels

Lee, K., Steinhauer, N.A., Travis, D.A., Meixner, M.D., Deen, J., et al. (2015) Honey bee surveillance: a tool for understanding and improving honey bee health. Curr. Opin. Insect Sci. 10, 1-8

Locke, B., Fries, I. (2011) Characteristics of honey bee colonies (Apis mellifera) in Sweden surviving Varroa destructor infestation. Apidologie 42, 533-542

McMenamin, A.J., Genersch, E. (2015) Honey bee colony losses and associated viruses. Curr. Opin. Insect Sci. 8, 121-129

OIE (2013) Nosemosis of bees, Manual of diagnostic tests and vaccines for terrestrial animals, Paris, pp. 380-388

Pohorecka, K., Bober, A., Skubida, M., Zdanska, D., Toroj, K. (2014) A comparative study of environmental conditions, bee management and the epidemiological situation in apiaries varying in the level of colony losses. J Apic Sci 58, 107-132

Potts, S.G., Roberts, S.P., Dean, R., Marris, G., Brown, M.A., et al. (2010) Declines of managed honey bees and beekeepers in Europe. J. Apic. Res. Bee World 49 (1), 15-22

Powell, C. (2003) The Delphi technique: myths and realities. J. Adv. Nurs. 41 (4), 376-382

Schaefer, M.O., Genersch, E., Funfhaus, A., Poppinga, L., Formella, N., et al. (2014) Rapid identification of differentially virulent genotypes of Paenibacillus lar$v a e$, the causative organism of American foulbrood of honey bees, by whole cell MALDI-TOF mass spectrometry. Vet. Microbiol. 170(3-4), 291-297

Sestelo, M., Villanueva, N.M., Roca-Pardinas, J. (2013) FWDselect: Variable selection algorithm in regression models. Discussion Papers in Statistics and Operation Research. University of Vigo, Vigo 
Spleen, A., Lengerich, E., Rennich, K., Caron, D., Rose, R., et al. (2013) A national survey of managed honey bee 2011-2012 winter colony losses in the United States: results from the Bee Informed Partnership. J. Apic. Res. 52 (2), 9

Steinhauer, N.A., Rennich, K., Wilson, M.E., Caron, D.M., Lengerich, E.J., et al. (2014) A national survey of managed honey bee 2012-2013 annual colony losses in the USA: results from the Bee Informed Partnership. J. Apic. Res. 53 (1), 1-18
vanderZee, R., Brodschneider, R., Brusbardis, W., Charrière, J.-D., Chlebo, R., et al. (2014) Results of international standardised beekeeper surveys of colony losses for winter 2012-2013: analysis of winter loss rates and mixed effects modelling of risk factors for winter loss. J. Apic. Res. 53 (1), 19-34

Vanengelsdorp, D., Meixner, M.D. (2010) A historical review of managed honey bee populations in Europe and the United States and the factors that may affect them. J. Invertebr. Pathol. 103, 80-95

\section{Annex}

Members of the EPILOBEE consortium

\begin{tabular}{lll}
\hline Belgium & & \\
De Graaf & Dirk & Ghent University, Department of Physiology, Laboratory of Zoophysiology \\
Méroc & Estelle & NRL for honeybee diseases CODA-CERVA-VAR \\
Nguyen & Bach Kim & Ulg, Faculté Gembloux Agro-Bio Tech \\
Roelandt & Sophie & NRL for honeybee diseases CODA-CERVA-VAR \\
Roels & Stefan & NRL for honeybee diseases CODA-CERVA-VAR \\
Van der Stede & Yves & NRL for honeybee diseases CODA-CERVA-VAR \\
Denmark & Tina & (NRL) Aarhus University \\
$\begin{array}{l}\text { Tonnersen } \\
\text { Kryger }\end{array}$ & Per & (NRL) Aarhus University \\
Estonia & Kärt & Estonian Veterinary and Food Board \\
Jaarma & Merle & Estonian Veterinary and Food Laboratory \\
Kuus & Arvi & Estonian Veterinary and Food Board \\
Raie & & Finnish Food Safety Authority EVIRA, Veterinary Bacteriology Research Unit, \\
Finland & Kirpa & Finnish Food Safety Authority EVIRA, Veterinary Bacteriology Research Unit, \\
Heinikainen & Kuopio \\
Pelkonen & Sinikka & Finnish Food Safety Authority EVIRA, Veterinary Bacteriology Research Unit, \\
Vähänikkilä & Nella & Kuopio
\end{tabular}

\section{France}

Andrieux

Christophe

Ballis

Alexis

Barrieu

Guy

Bendali

Fatah

Brugoux

Corinne

Franco

Stéphanie

Fuentes

Anne-Marie

Joel

Alain

Layec

Yves

Lopez

Jacqueline

Lozach

André

Malherbe-Duluc

Laure

Mariau

Viviane

DDPP du Cantal

Chambre d'Agriculture du Haut-Rhin

DDPP des Bouches du Rhône

Direction Générale de l'Alimentation

Groupement de Défense Sanitaire du Cantal

LNR Abeilles Anses Sophia Antipolis

Groupement de Défense Sanitaire de la Drôme

DDPP Finistère

Groupement de Défense Sanitaire Apicole du Finistère

DDPP Indre et Loire

Groupement de Défense Sanitaire Apicole du Finistère

Groupement de Défense Sanitaire Indre et Loire

DDPP Indre et Loire 


\begin{tabular}{|c|c|c|}
\hline Meziani & Fayçal & Direction Générale de l'Alimentation \\
\hline Monod & Denis & Groupement de Défense Sanitaire Apicole des Bouches du Rhône \\
\hline Mutel & Sébastien & DDCSPP Haut-Rhin \\
\hline Oesterle & Eric & Groupement de Défense Sanitaire Indre et Loire \\
\hline Orlowski & Muriel & DDPP de la Drôme \\
\hline Petit & Manuel & DDPP Finistère \\
\hline Pillu & Patricia & DDPP du Cantal \\
\hline Poret & Florence & Groupement de Défense Sanitaire du Cantal \\
\hline Viry & Alain & Laboratoire d'Analyses du Jura \\
\hline \multicolumn{3}{|l|}{ Germany } \\
\hline Berg & Stefan & $\begin{array}{l}\text { Bavarian State Institute for Viticulture and Horticulture, Bee Research Center, } \\
\text { Veitshöchheim }\end{array}$ \\
\hline Büchler & Ralph & LLH Bieneninstitut Kirchhain \\
\hline de Craigher & Doris & University of Hohenheim, Apicultural State Institute, Stuttgart \\
\hline Genersch & Elke & Institute for Bee Research, Hohen Neuendorf \\
\hline Kaatz & Hans-Hinrich & University of Halle-Wittenberg, Zoology Dept., Halle \\
\hline Meixner & Marina D. & LLH Bieneninstitut Kirchhain \\
\hline von der Ohe & Werner & LAVES Institut für Bienenkunde, Celle \\
\hline Otten & Christoph & $\begin{array}{l}\text { Dienstleistungszentrum Ländlicher Raum, Fachzentrum Bienen und Imkerei } \\
\text { Mayen }\end{array}$ \\
\hline Rosenkranz & Peter & University of Hohenheim, Apicultural State Institute, Stuttgart \\
\hline Schäfer & Marc O. & Institute of Infectology, Friedrich-Loeffler-Institut, Greifswald - Insel Riems \\
\hline Schroeder & Annette & University of Hohenheim, Apicultural State Institute, Stuttgart \\
\hline \multicolumn{3}{|l|}{ Greece } \\
\hline Agianiotaki & Eirini & Centre of Veterinary Institute of Athens \\
\hline Arfara & Stamatia & Centre of Veterinary Institute of Athens \\
\hline Boutsini & Sofia & Centre of Veterinary Institute of Athens \\
\hline Giannoulopoulou & Marianthi & Regional Veterinary Laboratory of Heraclio \\
\hline Hondrou & Varvara & Regional Veterinary Laboratory of Mytilini \\
\hline Karipidou & Sonia & Regional Veterinary Laboratory of Kozani \\
\hline Katsaros & Dimitrios & Regional Veterinary Laboratory of Chalkis \\
\hline Katzagiannakis & Aristomenis & Regional Veterinary Laboratory of Heraclio \\
\hline Kiriakopoulos & Antonios & Regional Veterinary Laboratory of Mytilini \\
\hline Oureilidis & Konstantinos & Regional Veterinary Laboratory of Kavala \\
\hline Panteli & Aspasia & Centre of Veterinary Institute of Athens \\
\hline Pantoleon & Fotis & Regional Veterinary Laboratory of Tripoli \\
\hline Papagianni & Zoi & Centre of Veterinary Institute of Athens \\
\hline Papalexiou & Eleni & Centre of Veterinary Institute of Athens \\
\hline Perdikaris & Socrates & Ministry of Rural Development and Food \\
\hline Prapas & Athanasios & Centre of Veterinary Institute of Athens \\
\hline Siana & Panagiota & Regional Veterinary Laboratory of Tripoli \\
\hline Skandalakis & Ioannis & Regional Veterinary Laboratory of Chania \\
\hline Stougiou & Despoina & Centre of Veterinary Institute of Athens \\
\hline Tomazinakis & Ioannis & Regional Veterinary Laboratory of Chania \\
\hline Tsali & Eleftheria & Regional Veterinary Laboratory of Larisa \\
\hline Tseliou & Evgenia & Regional Veterinary Laboratory of Kerkyra \\
\hline Tsiplakidis & Achillefs & Regional Veterinary Laboratory of Kavala \\
\hline
\end{tabular}




\begin{tabular}{|c|c|c|}
\hline Tsompanellis & Efstratios & Regional Veterinary Laboratory of Mytilini \\
\hline Vamvakas & Giorgos & Regional Veterinary Laboratory of Kozani \\
\hline Varvarouta & Vasiliki & Regional Veterinary Laboratory of Heraclio \\
\hline Vourvidis & Dimitris & Ministry of Rural Development and Food \\
\hline \multicolumn{3}{|l|}{ Hungary } \\
\hline Dán & Ádám & $\begin{array}{l}\text { National Food Chain Safety Office, Veterinary Diagnostic Directorate (NRL for } \\
\text { bee health) }\end{array}$ \\
\hline Daróczi & Gyöngyi & $\begin{array}{l}\text { National Food Chain Safety Office, Veterinary Diagnostic Directorate (NRL for } \\
\text { bee health) }\end{array}$ \\
\hline Láng & Mária & $\begin{array}{l}\text { National Food Chain Safety Office, Veterinary Diagnostic Directorate (NRL for } \\
\text { bee health) }\end{array}$ \\
\hline Papp & Melitta & $\begin{array}{l}\text { National Food Chain Safety Office, Veterinary Diagnostic Directorate (NRL for } \\
\text { bee health) }\end{array}$ \\
\hline Paulus & Petra, Deákné & $\begin{array}{l}\text { National Food Chain Safety Office, Veterinary Diagnostic Directorate (NRL for } \\
\text { bee health) }\end{array}$ \\
\hline Pupp & Eszter & $\begin{array}{l}\text { National Food Chain Safety Office, Veterinary Diagnostic Directorate (NRL for } \\
\text { bee health) }\end{array}$ \\
\hline Szaló & Márta & Ministry of Agriculture, Food Chain Control Department \\
\hline Tóth & Ádám & $\begin{array}{l}\text { National Food Chain Safety Office, Veterinary Diagnostic Directorate (NRL for } \\
\text { bee health) }\end{array}$ \\
\hline Zséli & Szilvia & $\begin{array}{l}\text { National Food Chain Safety Office, Animal Health and Animal Welfare } \\
\text { Directorate }\end{array}$ \\
\hline
\end{tabular}

\section{Italy}

$\begin{array}{ll}\text { Bressan } & \text { Gianluigi } \\ \text { Cerrone } & \text { Anna } \\ \text { Formato } & \text { Giovanni } \\ \text { Granato } & \text { Anna } \\ \text { Lavazza } & \text { Antonio } \\ \text { Macellari } & \text { Piero } \\ \text { Marcello } & \text { Paola } \\ \text { Ghittino } & \text { Claudio } \\ \text { Maroni Ponti } & \text { Andrea } \\ \text { Possidente } & \text { Rosaria } \\ \text { Mutinelli } & \text { Franco } \\ \text { Nassuato } & \text { Claudia } \\ \text { Pintore } & \text { Antonio } \\ \text { Ricchiuti } & \text { Luciano } \\ \text { Ruocco } & \text { Luigi } \\ \text { Salvaggio } & \text { Antonio } \\ \text { Troiano } & \text { Pasquale } \\ \text { Voltini } & \text { Barbara }\end{array}$

Ulss22, Bussolengo

IZS del Mezzogiorno

IZS delle Regioni Lazio e Toscana

IZS delle Venezie

IZS della Lombardia e dell'Emilia Romagna

Asl Umbria 1

ASL Sassari

IZS dell'Umbria e delle Marche

Ministero della Salute

IZS del Piemonte Liguria e Valle d'Aosta

IZS delle Venezie

Regione Lombardia

IZS della Sardegna

IZS dell'Abruzzo e del Molise

Ministero della Salute

IZS della Sicilia

IZS di Puglia e Basilicata

Regione Toscana

\section{Latvia}

$\begin{array}{ll}\text { Avsejenko } & \text { Jelena } \\ \text { Ciekure } & \text { Elïna } \\ \text { Deksne } & \text { Gunita } \\ \text { Eglïte } & \text { Ineta } \\ \text { Granta } & \text { Rita } \\ \text { Olševski } & \text { Edvïns }\end{array}$

Institute of Food safety, Animal Health and Environment, "BIOR" Institute of Food safety, Animal Health and Environment, "BIOR" Institute of Food safety, Animal Health and Environment, "BIOR" Latvian Beekeepers Association Institute of Food safety, Animal Health and Environment, "BIOR" Food and Veterinary Service of the Republic of Latvia 


\begin{tabular}{|c|c|c|}
\hline Rodze & Ieva & Institute of Food safety, Animal Health and $\mathrm{E}$ \\
\hline Stinka & Madara & Food and Veterinary Service of the Republic \\
\hline \multicolumn{3}{|l|}{ Lithuania } \\
\hline Sirutkaityte & Rasa & The State Food and Veterinary Service, Anim \\
\hline Siriukaitis & Sigitas & The State Food and Veterinary Service, Ani \\
\hline \multicolumn{3}{|l|}{ Poland } \\
\hline Bober & Andrzej & National Veterinary Research Institute, Pula \\
\hline Jażdżewski & Krzysztof & General Veterinary Inspectorate, Warsaw, $\mathrm{P}$ \\
\hline Pohorecka & Krystyna & National Veterinary Research Institute, Pula \\
\hline Skubida & Marta & National Veterinary Research Institute, Pula \\
\hline Zdańska & Dagmara & National Veterinary Research Institute, Pula \\
\hline \multicolumn{3}{|l|}{ Portugal } \\
\hline Amador & $\begin{array}{c}\text { Maria Rita } \\
\text { Ramos }\end{array}$ & Direção Geral de Alimentacão e Veterinaria \\
\hline Freitas & Susana & Direção Geral de Alimentacão e Veterinaria \\
\hline Quintans & Sofia & Direção Geral de Alimentacão e Veterinaria \\
\hline Santos & $\begin{array}{l}\text { Patricia } \\
\text { Tavares }\end{array}$ & Direção Geral de Alimentacão e Veterinaria \\
\hline
\end{tabular}

$\begin{array}{ll}\begin{array}{l}\text { Slovakia } \\ \text { Březinová } \\ \text { Brtková }\end{array} & \begin{array}{l}\text { Nicole } \\ \text { Čuvalová }\end{array} \\ \text { Filipová } & \text { Zuzana } \\ \text { Jurovčiková } & \text { Miriam } \\ \text { Kantíková } & \text { Júlia } \\ \text { Kubicová } & \text { Miriam } \\ \text { Papierniková } & \text { Zuzana } \\ \text { Šulejová } & \text { Erika } \\ \text { Toporčák } & \text { Lucia } \\ \text { Spain } & \text { Juraj }\end{array}$

\section{Spain}

Ares Cenador Carmen Maria

State Veterinary and Food Institute, Dolny Kubin, Slovakia

State Veterinary and Food Institute, Dolny Kubin, Slovakia

State Veterinary and Food Institute, Dolny Kubin, Slovakia

State Veterinary and Food Institute, Dolny Kubin, Slovakia

State Veterinary and Food Institute, Dolny Kubin, Slovakia

State Veterinary and Food Institute, Dolny Kubin, Slovakia

State Veterinary and Food Institute, Dolny Kubin, Slovakia

State Veterinary and Food Administration of the Slovak Republic

State Veterinary and Food Institute, Dolny Kubin, Slovakia

The University of veterinary medicine and pharmacy in Košice, Slovakia

$\begin{array}{ll}\text { Ariza } & \text { Javier } \\ \text { Berná Serna } & \text { Nieves } \\ \text { Cabeza Núñez } & \text { Amparo } \\ \begin{array}{l}\text { Casasempere } \\ \text { Cascales }\end{array} & \text { Jorge } \\ \text { Cid González } & \text { Carlos } \\ \text { Corzán Ripoll } & \text { Jose Manuel } \\ \begin{array}{l}\text { De Abajo } \\ \text { Domingo } \\ \text { Díaz Rey }\end{array} & \text { Miguel Ángel } \\ \text { Esteban Royo } & \text { Roberto } \\ \text { Fernández Somalo } & \text { Pilar }\end{array}$

Consejería de Agroganadería y Recursos Autóctonos del Principado de Asturias Consejería de Agricultura de La Junta de Comunidades de Castilla La Mancha GVA, Consejería de la Presidencia de Agricultura, Pesca, Alimentación y Agua Consejería de Agricultura y Pesca de la junta de Andalucía

GVA, Consejería de la Presidencia de Agricultura, Pesca, Alimentación y Agua

Subdireción Xeral de Gandería - Consellería do Medio Rural e do Mar - Xunta de Galicia

Consejería de Agricultura, Ganadería y Medio Ambiente, Diputación General de Aragón

Consejería de Agricultura y Ganadería de la Junta de Castilla y León

Subdireción Xeral de Gandería - Consellería do Medio Rural e do Mar - Xunta de Galicia

Consejería de Agricultura, Ganadería y Medio Ambiente, Diputación General de Aragón

SG de Sanidad, Higiene Animal y Trazabilidad del $\mathrm{M}^{\circ}$ Agricultura, Alim. y Medio Ambiente 


\begin{tabular}{|c|c|c|}
\hline $\begin{array}{l}\text { García } \\
\text { Pascualvaca }\end{array}$ & Alejandra & Consejería de Agricultura y Pesca de la junta de Andalucía \\
\hline González Breña & Carlos & $\begin{array}{l}\text { Consejería de Agricultura, Desarrollo Rural, Medio Ambiente y Energía, J. de } \\
\text { Extremadura }\end{array}$ \\
\hline Mínguez Gonzalez & Olga & Consejería de Agricultura y Ganadería de la Junta de Castilla y León \\
\hline Oñate & Maria Luisa & $\begin{array}{l}\text { Consejería de Agricultura, Ganadería y Medio Ambiente, Diputación General de } \\
\text { Aragón }\end{array}$ \\
\hline Oteiza Orradre & Pedro & $\begin{array}{l}\text { Dpto. de Desarrollo Rural, Industria, Empleo y Medio Ambiente, Diputación } \\
\text { Foral Navarra }\end{array}$ \\
\hline Pérez Cobo & Iratxe & $\begin{array}{l}\text { SG de Sanidad, Higiene Animal y Trazabilidad del } \mathrm{M}^{\circ} \text { Agricultura, Alim. y } \\
\text { Medio Ambiente }\end{array}$ \\
\hline Plaza Pérez & Margarita & Consejería de Agricultura y Agua de la Región de Murcia \\
\hline Puy Pitarque & D. Juan Ramón & Departamento de Agricultura, Pesca y Alimentación del Gobierno Vasco \\
\hline Riol Guinea & Rubén & Consejería de Agricultura y Ganadería de la Junta de Castilla y León \\
\hline Romero González & Luis José & $\begin{array}{l}\text { SG de Sanidad e Higiene Animal y Trazabilidad del } \mathrm{M}^{\circ} \text { Agricultura, Alim. y } \\
\text { Medio Ambiente }\end{array}$ \\
\hline $\begin{array}{r}\text { Soldevilla } \\
\text { Yanguas }\end{array}$ & Jose Fernando & $\begin{array}{l}\text { Consejería de Agricultura, Ganadería y Medio Ambiente, Comunidad Autónoma } \\
\text { de la Rioja }\end{array}$ \\
\hline Soler i Barrasús & Mercè & $\begin{array}{l}\text { Dept. Agricultura, Ramaderia, Pesca, Alimentación i Medi Natural, Generalitat } \\
\text { de Catalunya }\end{array}$ \\
\hline Soriano González & Mario & $\begin{array}{l}\text { Consejería de la Presidencia de Agricultura, Pesca, Alim. y Agua, Generalitat } \\
\text { Valenciana }\end{array}$ \\
\hline Vigo López & Virginia & Consejería de Agricultura, Ganadería, Pesca y Aguas del Gobierno de Canarias \\
\hline Villarta Rivas & José Luis & Consejería de Agricultura de La Junta de Comunidades de Castilla La Mancha \\
\hline \multicolumn{3}{|l|}{ Sweden } \\
\hline $\begin{array}{l}\text { Fabricius- } \\
\text { Kristiansen }\end{array}$ & Lotta & Swedish Board of Agriculture \\
\hline Forsgren & Eva & Department of Ecology, Swedish University of Agricultural Sciences \\
\hline \multicolumn{3}{|l|}{ UK } \\
\hline Brown & Mike & $\begin{array}{l}\text { The National Bee Unit (NBU) - Food and Environment Research Agency } \\
\text { (FERA) }\end{array}$ \\
\hline Budge & Giles & $\begin{array}{l}\text { The National Bee Unit (NBU) - Food and Environment Research Agency } \\
\text { (FERA) }\end{array}$ \\
\hline Grant & Ruth & $\begin{array}{l}\text { The National Bee Unit (NBU) - Food and Environment Research Agency } \\
\text { (FERA) }\end{array}$ \\
\hline Marris & Gay & $\begin{array}{l}\text { The National Bee Unit (NBU) - Food and Environment Research Agency } \\
\text { (FERA) }\end{array}$ \\
\hline Powell & Michelle & $\begin{array}{l}\text { The National Bee Unit (NBU) - Food and Environment Research Agency } \\
\text { (FERA) }\end{array}$ \\
\hline Wattam & Andy & $\begin{array}{l}\text { The National Bee Unit (NBU) - Food and Environment Research Agency } \\
\text { (FERA) }\end{array}$ \\
\hline Whiting & Ilex & $\begin{array}{l}\text { The National Bee Unit (NBU) - Food and Environment Research Agency } \\
\text { (FERA) }\end{array}$ \\
\hline \multicolumn{3}{|l|}{ EURL staff } \\
\hline Cauquil & Laura & \\
\hline Garin & Emmanuel & \\
\hline Rivière & Marie-Pierre & \\
\hline
\end{tabular}

